Research, part of a Special Feature on Local, Social, and Environmental Impacts of Biofuels

\title{
Environmental and Social Impacts of Oil Palm Plantations and their Implications for Biofuel Production in Indonesia
}

\author{
$\underline{\text { Krystof Obidzinski }}{ }^{1}, \underline{\text { Rubeta Andriani }}^{1}$, Heru Komarudin $^{1}{ }^{1}$, and Agus Andrianto ${ }^{1}$
}

\begin{abstract}
This paper reviews the development of oil palm with linkages to biofuel in Indonesia and analyzes the associated environmental and socioeconomic impacts. We selected three plantation study sites in West Papua (Manokwari), West Kalimantan (Kubu Raya), and Papua (Boven Digoel) to assess the impacts. Research findings indicate that the development of oil palm in all three sites has caused deforestation, resulting in significant secondary external impacts such as water pollution, soil erosion, and air pollution. In terms of social impacts, many stakeholder groups, i.e., employees, out-growers, and investing households, report significant gains. However, we found these benefits were not evenly distributed. Other stakeholders, particularly traditional landowners, experienced restrictions on traditional land use rights and land losses. We observed increasing land scarcity, rising land prices, and conflicts over land in all sites. Three major trade-offs are associated with the development of oil palm plantations, including those related to biofuels: unevenly distributed economic benefits are generated at the cost of significant environmental losses; there are some winners but also many losers; and economic gains accrue at the expense of weak rule of law. To reduce the negative impacts and trade-offs of oil palm plantations and maximize their economic potential, government decision makers need to restrict the use of forested land for plantation development, enforce existing regulations on concession allocation and environmental management, improve monitoring of labor practices, recognize traditional land use rights, and make land transfer agreements involving customary land more transparent and legally binding.
\end{abstract}

Key Words: biofuels, environmental impacts, oil palm, socioeconomic benefits

\section{INTRODUCTION}

In recent years, many countries around the world have been tapping renewable resources to secure stable sources of energy. This tendency has been spurred by high fossil fuel prices, rising demand for energy, and increasing concerns about the implications of fossil fuels on global climate (FAO 2008a). The European Union (EU) and United States of America (USA) are currently the leading markets for, and producers of, biofuels, but Brazil and the emergent economies of China and India are not far behind (Emerging Markets Online 2008, Biodiesel Magazine Editorial Staff 2010). The growth in biofuels has been achieved primarily by introducing fuel-blending obligations and government subsidies (FAO $2008 b$ ). Over the past two years, following the initial excitement over biofuels' potential as a clean source of energy, increasing concerns have emerged regarding the potential environmental and socioeconomic costs of large-scale biofuel feedstock cultivation, especially in developing countries (Cotula et al. 2008, Danielsen et al. 2008, Sheil et al. 2009, Gibbs et al. 2010). As a result, some major markets, such as those in the EU, have adopted production and trade safeguards, e.g., Renewable Energy Directive (RED), that require biofuels consumed in the EU to meet defined sustainability standards, regardless of their origin (EU 2006, Ismail and Rossi 2010).

Indonesia is potentially a key supplier of biofuels, especially oil palm-based biodiesel, to world markets. In 2006, the country had 4.1 million ha of oil palm plantation, $31 \%$ of the world total (Koh and Wilcove 2008). By 2010, the plantation area increased to about 7.2 million ha of oil palm, which accounted for $46 \%$ of the world's crude palm oil (CPO; FAO 2008a, Bromokusumo 2009, Bromokusumo and Slette 2010, Teoh 2010).

Currently, Malaysia is the regional leader in biodiesel production with an output of 540 million liters per annum as of 2009 (Teoh 2010). Indonesia is second with the production of 400 million liters in 2010 (Slette and Wiyono 2011). By 2019, Indonesia and Malaysia are forecast to nearly double their production of biodiesel, respectively (FAO 2008a, Hoh 2009, FAPRI 2010). By 2025, it is forecast that biodiesel, mostly from CPO, and other biofuels will constitute $25 \%$ of Indonesia's national energy mix (Timnas BBN 2007).

Biofuels have increasingly attracted the Indonesian government's interest because of their potential to reduce the country's reliance on imported fossil fuels (Dillon et al. 2008). As a result, in 2006, the government made use of biofuels for transport mandatory and established blending targets at $5 \%$ in $2006,10 \%$ in 2010 , and increasing to $25 \%$ by 2025 . In early 2007 , the government announced that 60 biofuel projects worth about US $\$ 12$ billion would be developed (Business Wire 2007). However, few of these investments have been implemented; the global financial crisis of 2008 and rising CPO prices made biofuels too costly and uncompetitive visà-vis fossil fuels. This caused biofuel refineries that had just commenced operations to reduce production or close indefinitely (Lacey 2009). 
In late 2009 and 2010, as international economic conditions improved, the biofuel sector showed signs of revival. At the same time, country-level policies in Indonesia moved increasingly toward securing and sustaining the growth of biofuels by supporting large-scale plantation investments and prioritizing the development of biofuels on marginal or "idle" land (Hallam 2009). Between 2010 and 2020, experts expect between three and seven million ha of new oil palm plantations will be developed for food and biofuel (Gingold 2010). Some estimates run as high as 20 million ha based on the concession permits issued at various administrative levels in Indonesia. Historically, however, only one-third of allocated oil palm plantation concessions has actually been developed because of the high-risk business environment (Slette and Wiyono 2011).

Expansion plans for oil palm plantations in Indonesia have become the subject of political and environmental debates. Some see oil palm as a commodity playing an important role in mitigating climate change, providing alternative sources of energy, and contributing to economic development and rural livelihoods (Basiron 2007; Y. Basiron, unpublished manuscript). Others are concerned about potentially serious unintended social, economic, and environment implications (Fitzherbert et al. 2008, ICTSD 2008, Marti 2008, Bringezu et al. 2009, Sheil et al. 2009, Sirait 2009, Colchester 2010, FoE 2010).

This ongoing debate is important, and will likely determine the future of first-generation biofuels. Arguments in favor and against oil palm and biofuels are based on sectoral and institutional interests and also on different, often superficial, methods to assess the benefits or costs of oil palm. Using a systematic and empirical approach to shed light on the local social, economic, and environmental impacts of oil palm development in Indonesia, we seek to inform the ongoing debate. We examine oil palm plantations supporting biofuel production or undergoing expansion or acquisition processes associated with bioenergy. We also analyze the impacts of oil palm plantation development and highlight the potential implications of CPO-based biofuels in three sites, one in West Kalimantan with an established tradition of oil palm cultivation, and two in Papua and West Papua provinces with more recent operations. The impact assessment focuses on landowners, customary users, investing households, employees, and affected neighbors.

\section{OVERVIEW OF OIL PALM AND BIOFUEL DEVELOPMENT IN INDONESIA: PROGRESS AND ISSUES}

\section{Oil palm plantation business models}

As of early 2011, oil palm plantations covered 7.8 million ha in Indonesia, out of which 6.1 million ha were productive plantations under harvest (Slette and Wiyono 2011). In 2010, these plantations produced 22 million tons of $\mathrm{CPO}$ and the production increased further to 23.6 million tons by the end of 2011.

Most plantations, as well as CPO production, are located in Sumatra and Kalimantan (Indonesian part of Borneo). Between 1997 and 2006, 400,000 ha of oil palm plantations were established annually. Between 2007 and 2010, the size of annual establishment of oil palm plantations declined to 350,000 ha (Slette and Wiyono 2011). As new land available for plantations becomes more limited, annual development of plantation is expected to continue its gradual decline. However, over the next few years, land concessions already allocated for oil palm and not yet developed are sufficiently large to allow plantation estates to continue growing.

There are three main types of business models for oil palm cultivation in Indonesia: private large-scale plantations and two types of smallholder models, i.e., nucleus estate smallholders, or NES, and independent smallholders. Smallholders manage nearly half of the overall plantation area; unfortunately government statistics do not distinguish between different types of smallholders. It is believed that smallholder operations have contributed significantly to the expansion of oil palm estates in recent years (World Bank 2010).

Between 2006 and 2010, the area of oil palm plantations increased by 2.37 million ha, bringing the total productive area of plantation estates to 5.9 million ha (Slette and Wiyono 2011). This was partly because of biofuel and oil palm policies, which took effect in 2006 aiming to promote the production and use of biofuels. Overall, however, this expansion is more closely associated with the rising demand for CPO for food, both domestically and for export (Caroko et al. 2011). In 2011, the area of productive oil palm plantation subject to harvest increased to 6.1 million ha (Slette and Wiyono 2011). In theory, this area alone could be sufficient to meet Indonesia's current CPO needs and future production expansion targets if the standard average production of six tons of CPO per hectare could be implemented across the entire sector (Table 1). It is possible, however, that not all areas reported as oil palm plantation are actually planted. In Kalimantan and Sumatra, only about half of the land areas allocated for oil palm plantations have been developed into productive estates (Slette and Wiyono 2011).

Most independent smallholders operate in North Sumatra and West Kalimantan, areas with a long history of oil palm cultivation on large-scale estates, as well as smallholder operations (Jelsma et al. 2009). There are several variants of the NES model (Jelsma et al. 2009). One involves the development of both NES as large-scale estates, also known as Inti or Nucleus, as well as small plantation plots, known as Plasma. Once the oil palm trees start bearing fruit, normally four years after planting, the company transfers plots to 
smallholders who then deliver fruits to company mills at agreed upon prices.

Table 1. Oil palm area and palm oil production 1970-2010.

\begin{tabular}{|c|c|c|c|c|c|c|c|c|}
\hline \multirow[b]{2}{*}{ Year } & \multicolumn{4}{|c|}{$\begin{array}{c}\text { Palm oil area } \\
\text { (million of hectares) }\end{array}$} & \multicolumn{4}{|c|}{$\begin{array}{l}\text { Palm oil production } \\
\text { (million of tons) }\end{array}$} \\
\hline & $\begin{array}{l}\text { Small- } \\
\text { holders }\end{array}$ & $\begin{array}{c}\text { State } \\
\text { owned }\end{array}$ & $\begin{array}{l}\text { Private } \\
\text { estates }\end{array}$ & Total & $\begin{array}{l}\text { Small- } \\
\text { holders }\end{array}$ & $\begin{array}{c}\text { State } \\
\text { owned }\end{array}$ & $\begin{array}{l}\text { Private } \\
\text { estates }\end{array}$ & Total \\
\hline 1970 & - & 0.09 & 0.05 & 0.13 & - & 0.15 & 0.07 & 0.22 \\
\hline 1980 & 0.01 & 0.20 & 0.09 & 0.29 & 0.00 & 0.50 & 0.22 & 0.72 \\
\hline 1990 & 0.29 & 0.37 & 0.46 & 1.13 & 0.38 & 1.25 & 0.79 & 2.41 \\
\hline 2000 & 1.17 & 0.59 & 2.40 & 4.16 & 1.91 & 1.46 & 3.63 & 7.00 \\
\hline 2005 & 2.36 & 0.53 & 2.57 & 5.45 & 4.50 & 1.45 & 5.91 & 11.86 \\
\hline 2010 & 3.31 & 0.62 & 3.89 & 7.82 & 7.77 & 2.09 & 9.98 & 19.84 \\
\hline
\end{tabular}

Source: Modified from Ministry of Agriculture (2011)

Sometimes smallholder oil palm planting is connected to transmigration programs, which used to stimulate economic development in remote areas (PIR transmigrasi or NES transmigration). In this case, a plantation developer plants oil palm on the land belonging to transmigration settlers ( 2 ha per family) and sells the produce to the plantation company at the specified price. A more refined version of PIR transmigrasi is PIR KKPA (Kredit Koperasi Primer untuk Anggota, or basic cooperative credit), under which transmigrants can obtain subsidized bank loans (Potter and Lee 1998).

\section{Slow growth of biofuels}

Since 2006, biofuels have increasingly attracted the Indonesian government's interest because of their potential to reduce the country's reliance on fossil fuels (Beyond Petroleum 2010). Because Indonesia has long been dependent on fossil-fuel energy for revenues and to finance development, it has become increasingly urgent to conserve remaining oil reserves and look for alternative sources of energy. In 2005, revenue from the oil and gas sector was about US $\$ 19.2$ billion ( $24 \%$ of Indonesia's GDP). However, production levels of Indonesian oil have declined over the past decade while consumption has increased. In 2004, Indonesia became a net importer of oil (Beaton and Lontoh 2010).

The cost of extensive subsidies on fossil fuel products has been a related concern (Dillon et al. 2008). These subsidies are particularly burdensome because they consume large financial resources that could have been used more effectively for development or other national needs (Beaton and Lontoh 2010). In 2010, the government allocated US\$21.9 billion for fuel subsidies; this was about $15 \%$ of total government spending that year and thus continues to place a significant strain on the state budget (Kaiser 2011). Consequently, government policy makers have been eager to find ways to reduce these costs; biofuels appeared as a strategy of choice.

As part of the 2006 National Energy Policy, the Ministry of Energy set guidelines for the mandatory use of biodiesel by heavy industries, as well as blending targets. The government has actively encouraged investors to apply for land and industrial licenses. It was expected that by 2010, the biofuel industry would have created 3.6 million jobs in rural areas and helped reduce poverty by $16 \%$ (Ministry of Energy and Mineral Resources 2006, Dillon et al. 2008, Oxfam 2008, Sheil et al. 2009).

These targets have clearly not been reached. In 2010, biodiesel production of 400,000 kiloliters required about 410,000 metric tons (MT) of CPO (Slette and Wiyono 2011); this required approximately 100,000 ha of oil palm plantations. A plantation area of this size would employ between 10,000 and 20,000 workers (Sandker et al. 2007), far below official expectations.

In 2007, the first year that Indonesia's biofuel policy went into effect, investment in the biofuel sector was initially significant. In addition to private sector actors, banks and government institutions supported the growth (Ministry of Energy and Mineral Resources 2006). However, in late 2007, the Indonesian Association of Biofuel Producers (APROBI) reported that 17 biodiesel companies had reduced production or temporarily suspended operations. In 2008, only five mills were operating, which caused biodiesel production to fall by $60 \%$ (A. Sugiyono, unpublished manuscript). The decline was caused by the drop in price of fossil fuels on the international market and the spike in the price of the main biofuel feedstock (crude palm oil, CPO), which made CPO-based biofuels uncompetitive. The price of CPO on international markets is variable, but has recently been rising. In March 2008, it peaked at US $\$ 1410$ per ton. Throughout 2011, it hovered at around US\$1000 per ton.

There are other constraints on CPO-based biofuel development in Indonesia as well. Oil palm companies tend to sell most of their CPO production to domestic and foreign food markets, which offer best prices and the most buyers. About $25.7 \%$ of Indonesia's annual CPO production is consumed as cooking oil and other edible fats; about $73 \%$ is exported, mostly for food; and only $1.3 \%$ is used for biofuels.

In 2007, eight CPO biodiesel refineries operated in Indonesia with a combined annual processing capacity of 765,000 tons of CPO. In mid-2007, because of the aforementioned increase in $\mathrm{CPO}$ prices, the initial blending target in Indonesia was temporarily reduced from $5 \%$ to $2.5 \%$; refineries were reported to be operating on a fraction of their production capacity. Despite these difficulties, Indonesia's biodiesel sector has endured and over the years has shown modest production growth (Table 2). Still, biofuels development has fallen far short of expectations in terms of the rate of production growth and contribution to the national economy. 
Table 2. Indonesian biodiesel production and the use of palm oil. $\mathrm{CPO}=$ crude palm oil.

\begin{tabular}{cccccc}
\hline \hline 2006 & 2007 & 2008 & 2009 & 2010 & 2011 \\
\hline $\begin{array}{c}\text { Production (kiloliter) } \\
24,000\end{array}$ & 35,000 & 110,000 & 350,000 & 400,000 & 400,000 \\
CPO requirement (metric tons) \\
25,000 & 36,000 & 113,000 & 360,000 & 410,000 & 410,000 \\
\hline
\end{tabular}

Note: adapted from Slette and Wiyono (2011)

\section{Social implications}

It is generally accepted that oil palm plantations are an important driver of economic development in Indonesia because they contribute to state revenues and provide employment in rural areas (Basiron 2007, Bunyamin 2008, Feintrenie et al. 2010). In a study assessing the impacts of the nucleus model of oil palm plantations in West Kalimantan, Bunyamin (2008) found a steady increase in the sector's contribution to provincial GDP and farmer incomes. Other studies also indicate economic benefits for smallholders in Indonesia (Feintrenie et al. 2010). However, because oil palm cultivation requires a significant investment and a certain amount of experience, these benefits seem to accrue to those above a certain threshold of agricultural skill and income. Thus, oil palm development in Kalimantan is likely to benefit migrant smallholders with prior exposure to oil palm more than indigenous people with no prior experience, such as native Papuans (A. Hadianto, F. Kesaulija, personal communications).

In some cases, oil palm can also be detrimental to local livelihoods (L. Potter, unpublished manuscript). Orth (2007) shows that oil palm development in Central Kalimantan has adversely affected the shifting cultivation practices of the local Dayak communities, causing food insecurity. Oil palm plantations, especially large-scale estates, have frequently been associated with negative social impacts on rural communities and indigenous people (Telapak 2000, Marti 2008, Sirait 2009, FoE 2010). Although oil palm frequently appears to improve income, it affects social relations and land ownership in rural areas in ways that may ultimately work against the well-being of poor people (McCarthy 2010). Marti (2008) found many cases of human rights abuse by plantation companies, especially during land acquisition and plantation development. Other studies indicate that most conflicts between plantation developers and communities occur because of lack of recognition of customary rights, breached agreements, and disregard for the environment (Casson 2002, Colchester et al. 2006, Sawit Watch 2006, as cited in Down to Earth 2007; L. Potter, unpublished manuscript). Colchester (2010) reports that in 2010 no fewer than 630 land disputes between palm oil companies and local communities had taken place in Indonesia.

\section{Environmental concerns}

Deforestation is one of the key issues faced by the oil palm industry, especially in Indonesia where lowland rainforests contain high levels of biodiversity, and peat lands are home to globally significant carbon reserves. Although it is generally agreed that oil palm plantations have resulted in deforestation in Indonesia (Zakaria et al. 2007, Ministry of Environment 2009, Gibbs et al. 2010), the actual extent, and whether oil palm has been the prime driver, is subject to debate. For example, the Indonesian Oil Palm Research Institute (IOPRI) claims that only $3 \%$ of all oil palm plantations have been established in primary forests, whereas $63 \%$ have been developed in secondary forests and scrubland (IFCA 2008). Casson (2000) shows that, between 1982 and 1999, about six million ha of forestland were converted into oil palm plantations. Using the ratio of biofuel production to total oil production, industry insiders indicate that biofuels currently account for approximately $6.5 \%$ (some $65,000 \mathrm{ha}$ ) of annual deforestation in Indonesia (Y. Gao, personal communication).

In 2008, based on official government statistics, around 22.7 million ha of forestlands were available for conversion under the Hutan Produksi Konversi (HPK) forest land category, i.e., forest zone allocated for conversion to nonforestry purposes. By 2010, about 11 million ha of land were allocated for oil palm plantations on the islands of Sumatra and Kalimantan (Slette and Wiyono 2011). Only half of this area has been developed into productive plantation estates. However, large areas of forest seem to have been cleared but not planted. This reflects a trend in the plantations sector in Indonesia to target forested areas for conversion; the sector generates profits from timber either as an end in itself or as a means to generate additional capital for plantation development (Casson et al. 2007, Sheil et al. 2009). Some companies have cleared forest, but eventually ceased operations because of conflicts with local communities. However, others have simply not been managed well and either stagnated or went bankrupt.

The conversion of natural forests for oil palm plantations has been associated with the loss of biodiversity, including a decline in populations of iconic species such as Orangutan (Genus Pongo) and the Sumatran Tiger (Panthera tigris sumatrae; Brown and Jacobson 2005, Yaap et al. 2010). Oil palm is considered a relatively poor replacement for natural tropical forest. Recent studies indicate that it ranks behind planted forest, agroforest, and community woodlots in terms of the number of species it can support (Fitzherbert et al. 2008).

Forest conversion and plantation development as currently practiced are also significant sources of GHG emissions. Deforestation and land conversion contribute $15 \%$ to $25 \%$ of global carbon emissions. Converting lowland tropical rainforest to oil palm plantations is estimated to result in a carbon debt of $610 \mathrm{Mg}$ of CO2 ha-1, which would take between 86 to 93 years to repay (PEACE 2007, Danielsen et al. 2008, Fargione et al. 2008). For plantations established in peat lands, 
the carbon debt would be much higher, $6000 \mathrm{Mg}$ of CO2 ha- 1 ; this would take over 840 years to repay (Fargione et al. 2008) An estimated 1.7 million ha of oil palm plantations in Indonesia have been established on carbon-rich peat land (Kompas 2010a).

\section{METHODS}

\section{Stakeholders' selection and sampling methods}

The research team followed the standard methodology for the analysis of environmental and socioeconomic impacts, applied consistently in all sites for the purposes of comparison. We selected research sites to represent a variety of business models as well as possible environmental and local social impacts from oil palm plantations in Indonesia. For analysis of local social and environmental impacts, we used three different sources of data collection, i.e., household surveys, focus group discussions, and key informant interviews. In this way, we could triangulate the collected information to minimize uncertainty and error.

Stakeholders were determined to represent the variety of groups affected by the oil palm plantations in each type of business model. We selected stakeholders to represent various actors that are directly or indirectly affected by oil palm plantations. Five different stakeholder groups were identified for household surveys and focus group discussions:

- employees: nucleus estate laborers or farmer workers;

- former landowners: individual family groups whose customary land has been converted to nucleus estate and land using community members who are not customary landowners, but whose land has been converted for nucleus estate;

- customary users: community groups who have de facto rights over the lands;

- investing households: independent growers, who voluntarily invest in oil palm, or participating farmers who join PIR, PIR-Transmigrasi, and KKPA programs;

- affected neighbors: respondents who do not belong to any of the other groups.

Although all stakeholder groups are found in sites 1 and 2, site 3 lacks the investing households' group because of the nature of the private company's business model. The employees' group includes mostly unskilled workers employed in plantation nurseries, fruit harvesting, and others. In sites 1 and 2 , most unskilled workers live in surrounding villages, whereas in site 3 they live in the barracks on the plantation estate.

The household surveys employed generic questionnaires aimed to obtain respondents' personal experience of the impacts of oil palm plantation. A snowball sampling method selected respondents for the household surveys. We first approached and interviewed the local influential persons to help identify other groups of respondents for household surveys in each site. Social relations in sites 1 and 3 communities in Papua feature the 'big man' concept, which means that clan members are not able to speak and act freely about customary land matters (Mansoeben 1995, ZimmerTamakoshi 1997). This had implications for how we selected respondents, particularly former landowners and lessors. In site 3 , the research team selected clan heads or males assigned by clan leaders to obtain reliable information. In site 1 , where local norms for the big man are less pronounced because of a relatively high degree of interactions with the outsiders, the research team was able to interview other clan members as well.

We selected members for focus group discussions (FGD) using purposive sampling to capture as diverse a range of opinions as possible about the local impacts of oil palm. Through open-ended questions, FGD also helped verify information collected from individuals and households and to gather additional relevant data. We tried to reflect the existing diversity in terms of wealth, age, ethnicity, gender, and the nature of impacts. Separate discussions were held with men and women who were former landowners and investing households. This ensured that a group with a diversity of experience and different stakes in plantations was engaged in the analysis.

Finally, we collected secondary data and held semistructured interviews with key government officials, company representatives, and civil society organizations to complement the site-specific survey data. This produced a broader view on important issues relevant to oil palm and biofuel development.

All told, we interviewed 386 respondents in the 3 sites. Table 3 shows the distribution of each respondent group for any given site.

Table 3. Number of respondents of each group.

\begin{tabular}{lcccc}
\hline \hline & $\begin{array}{c}\text { Employees of } \\
\text { the oil palm } \\
\text { plantations }\end{array}$ & $\begin{array}{c}\text { Former } \\
\text { landowners, } \\
\text { lessors, and } \\
\text { customary users }\end{array}$ & $\begin{array}{c}\text { Investing } \\
\text { househ- } \\
\text { olds }\end{array}$ & $\begin{array}{c}\text { Former land } \\
\text { users and } \\
\text { affected } \\
\text { 'neighbors' }\end{array}$ \\
\hline Site 1 & 38 & 41 & 30 & 28 \\
Site 2 & 30 & 60 & 30 & 30 \\
Site 3 & 47 & 15 & NA & 35 \\
\hline
\end{tabular}

We analyzed environmental impacts using remote sensing techniques. For example, to understand land cover changes over time, we examined a time series of Landsat images covering each site (Table 4). Landsat data were downloaded from the United States Geological Survey's website (USGS 2011). The three images illustrate the sites before plantation 
Table 4. Landsat images used for spatial analysis.

\begin{tabular}{|c|c|c|c|c|c|c|c|}
\hline \multirow[b]{2}{*}{ Site No } & \multirow[b]{2}{*}{$\begin{array}{c}\text { Year plantation } \\
\text { operations } \\
\text { initiated } \\
\end{array}$} & \multicolumn{2}{|c|}{ Period 1} & \multicolumn{2}{|c|}{ Period 2} & \multicolumn{2}{|c|}{ Period 3} \\
\hline & & $\begin{array}{l}\text { Landsat type; } \\
\text { path/row }\end{array}$ & $\begin{array}{c}\text { Date of } \\
\text { acquisition }\end{array}$ & $\begin{array}{l}\text { Landsat type; } \\
\text { path/row }\end{array}$ & $\begin{array}{c}\text { Date of } \\
\text { acquisition }\end{array}$ & $\begin{array}{l}\text { Landsat type; } \\
\text { path/row }\end{array}$ & $\begin{array}{l}\text { Date of } \\
\text { acquisition }\end{array}$ \\
\hline 1 & 1982 & $\begin{array}{l}\text { Landsat 1MSS; } \\
\text { 113/61 and Landsat } \\
\text { 4MSS; } 105 / 61\end{array}$ & $\begin{array}{l}\text { 19-Oct-72 and } \\
11-\text { Dec-82 }\end{array}$ & $\begin{array}{c}\text { Landsat 4TM; } 105 / 61 \\
\text { and Landsat 4TM; } \\
106 / 61\end{array}$ & $\begin{array}{l}\text { 2-Apr-89 and } \\
\text { 9-Jan-91 }\end{array}$ & $\begin{array}{c}\text { Landsat } \\
\text { 5TM;105/61 and } \\
\text { Landsat 5TM; 106/61 }\end{array}$ & $\begin{array}{l}\text { 12-Jun-06 and } \\
\text { 6-Aug-06 }\end{array}$ \\
\hline 2 & 1994 & Landsat 5TM; 121/60 & 29-Jun-89 & $\begin{array}{c}\text { Landsat } \\
\text { 7ETM;121/60 }\end{array}$ & 22-Jun-01 & $\begin{array}{c}\text { Landsat } \\
\text { 7ETM;121/60 }\end{array}$ & 11-May-09 \\
\hline 3 & 1998 & Landsat 5TM; 100/65 & 20-Nov-90 & $\begin{array}{c}\text { Landsat } \\
\text { 7ETM;100/65 }\end{array}$ & 28-Oct-02 & Landsat 5TM; 100/65 & 23-Dec-08 \\
\hline
\end{tabular}

operations to ascertain the original land cover; plantation projects at the midpoint in their life cycle; and the most recent period available.

Depending on the availability of the Landsat data, if a plantation concession was obtained, for example, in 1990, the first image would be from just before 1990, the second from 2000, and the third as close to 2010 as possible. In the case of site 1, a combination of two Landsat scenes (Prafi A and Prafi B) were used for each period because no single Landsat scene covers the entire concession area. The time series analysis is intended to show land use and forest cover changes as a result of oil palm plantation development. Household survey questionnaires elicited qualitative information about the environmental changes ascribed by informants to oil palm plantation development.

\section{Research sites}

In recent years, the provinces of West Kalimantan, Papua, and West Papua have been among the most active areas in oil palm plantation development. Of the 3.5 million ha of new oil palm plantation proposals submitted to the government by 2009 , $70 \%$ were in these three provinces (Kardono, unpublished manuscript).

By 2011, Papua was processing 1.5 million ha of oil palm plantation permits and had another 2 million ha at the state of preliminary proposals (Papua Province Bureau for Plantation Estates, April 2011, personal communication). This activity, which solidified Papua's position as the last frontier in Indonesia for large-scale land investments, has been at least partly because of support from the provincial government. In 2008 , the governor issued a policy encouraging pro-poor rural development through oil palm plantations for biofuel production (USAID 2009). However, Papua is also one of Indonesia's flagship provinces to tackle climate change. As such, Papua's governor also actively promotes the province's commitment to a low-carbon economy and limits forest conversion to plantation estates (Suebu 2009).
Government-owned PT Perkebunan Nusantara XIII established the first large-scale oil palm plantation in West Kalimantan in the 1980s. In addition, large national and multinational groups such as Sinar Mas, Wilmar, Golden Hope, Cargill, and Lyman control major oil palm plantations in the province. According to official statistics, 337 oil palm plantations covered a total of 3.6 million ha in 2009 (Disbun Kalbar 2010).

We selected one site in each of the three provinces for the analysis of the impacts and trade-offs of oil palm plantations with links to biofuels: Manokwari District, West Papua; Kubu Raya District, West Kalimantan; and Boven Digoel District, Papua (Figure 1 and Table 5). The three districts have different geographic and land cover. In addition, the selected sites have connections to biofuel production, although none focus exclusively on supplying CPO for biofuels. Site 2 is a subsidiary of Wilmar, one of the largest biofuel producers in Indonesia. Sites 1 and 3 have shipped CPO to major biodiesel production centers in Indonesia. Table 5 summarizes the research sites.

Fig. 1. Location of research sites in Indonesia.

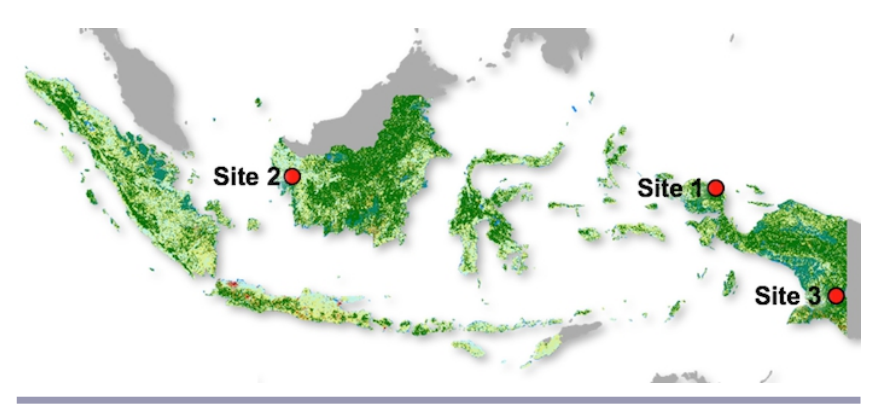

In site 1, the indigenous communities belong to the Arfak tribe, who are highly dependent on the forest for subsistence needs (Laksono et al. 2001). Originally, patrilineal genealogical ties 
shaped Arfak families and clans with communities living in large clan houses next to their gardens and farm land. This began to change at the end of the 19th century with the arrival of the Dutch government and Christian missionaries. The Dutch colonial government united Arfak family groups into villages for better control and more effective implementation of development, educational, and health programs. Currently, most Arfak communities continue to live in these villages, although some settlements have been moved several times (F. Kesaulija, personal communication).

Table 5. A summary of the research sites.

\begin{tabular}{|c|c|c|c|}
\hline Parameter & $\begin{array}{c}\text { Manokwari, } \\
\text { Papua }\end{array}$ & $\begin{array}{c}\text { Kubu Raya, West } \\
\text { Kalimantan }\end{array}$ & $\begin{array}{c}\text { Boven Digoel } \\
\text { Papua }\end{array}$ \\
\hline Company & PTPN II & PT. BPK & PT. TSE \\
\hline Status & State-owned & Private & Private \\
\hline Group & PTPN & Wilmar & Korindo \\
\hline $\begin{array}{l}\text { Size of } \\
\text { concession }\end{array}$ & 12,049 ha & 13,605 ha & 34,000 ha \\
\hline $\begin{array}{l}\text { Date of } \\
\text { establishment }\end{array}$ & 1982 & 1994 & 1998 \\
\hline Planted area & 10,207 ha & 5350 ha & 18,804 ha \\
\hline Business model & $\begin{array}{c}\text { Nucleus estate } \\
\text { smallholders } \\
\text { [ratio 27:73]; PIR } \\
\text { Trans; PIR KKPA }\end{array}$ & $\begin{array}{c}\text { Nucleus estate } \\
\text { smallholders } \\
\text { [ratio 70:30]; PIR; } \\
\text { PIR KKPA }\end{array}$ & $\begin{array}{c}\text { Private [ratio } \\
\text { 100:0] }\end{array}$ \\
\hline Labor regime & $\begin{array}{l}\text { Workers and } \\
\text { farmers }\end{array}$ & $\begin{array}{l}\text { Workers and } \\
\text { farmers }\end{array}$ & Worker \\
\hline Land type & Mineral soil & $\begin{array}{c}\text { Peat land ( } 0.5 \text { to } 6 \\
\text { m deep) }\end{array}$ & Mineral soil \\
\hline Land cover & Secondary forests & Secondary forests & $\begin{array}{l}\text { Primary } \\
\text { forests }\end{array}$ \\
\hline
\end{tabular}

In site 2, the native community is Dayak Ahe. They are an amalgamation of Dayak indigenous groups that lived in the hinterland in colonial times but subsequently migrated closer to the coast and, in the process, intermarried with local Malay groups and Madurese migrants. There are also small groups of Chinese and Javanese settlers in the area (G. Anshari, personal communication).

In site 3, the study site is controlled by 5 clans of the Mandobo tribe, 11 clans of the Jair tribe, and 25 clans of the Awyu tribe. All three tribes feature the big man concept; this determines allocation and use of natural resources. All customary land in this site de facto belongs to the clans. Individuals or families from specific clans can use the land for hunting, gathering, fishing, and farming. However, the clan head and other clan members must give collective approval for the transfer of land (A. Andrianto, personal observation).

\section{RESULTS}

Analysis of collected data confirms concerns about the environmental impact of oil palm plantations on forested landscapes. At the same time, the household survey showed significant economic gains from oil palm plantations, although these were not available to all stakeholders and were not distributed evenly.

\section{Environmental impacts}

Analysis of the time series of satellite images shows that oil palm plantations in all three research sites have led to deforestation. Figures 2, 3, and 4 illustrate the land cover change analysis for sites 1,2 and 3, respectively.

Fig. 2. Land cover change analysis for site 1 at three points in time: (a) 1972/82 (prior to plantation establishment); (b) 1989/91; and (c) 2006.

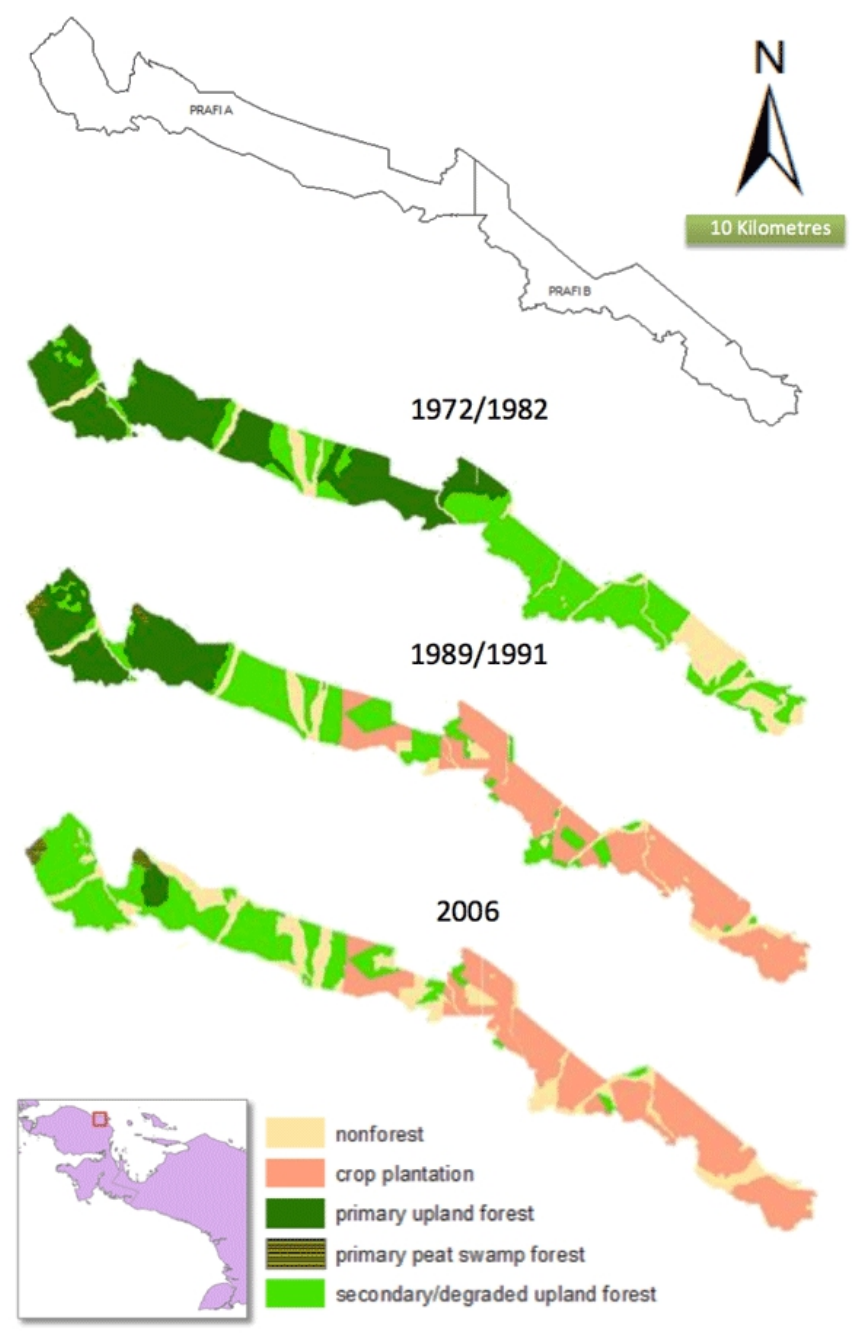

Table 6 illustrates the land cover change as a result of oil palm development. Table 7 summarizes the extent of deforestation and percentage of oil palm expansion that occurs at the expense of forests in all three sites.

According to field observations and interviews, oil palm plantations also caused environmental impacts (Table 8). Specifically, plantations degraded adjacent forest areas by displacing timber-extraction activities for construction and firewood use, and by concentrating these activities in 
Table 6. Land cover change in all sites (hectares).

\begin{tabular}{|c|c|c|c|c|c|c|c|}
\hline \multirow[b]{2}{*}{ Site } & \multirow[b]{2}{*}{ Land cover class } & \multicolumn{2}{|c|}{$\begin{array}{c}\text { Prior to Plantation Establishment } \\
\text { (ha) }\end{array}$} & \multicolumn{2}{|c|}{ Midpoint (ha) } & \multicolumn{2}{|c|}{ Most Recent Image (ha) } \\
\hline & & Prafi A & Prafi B & Prafi A & Prafi B & Prafi A & Prafi B \\
\hline \multirow{7}{*}{$\begin{array}{l}\text { Site } 1(12,049 \\
\text { ha concession) }\end{array}$} & Primary upland forest & 5435.48 & 0 & 2794.00 & & 260.44 & \\
\hline & $\begin{array}{l}\text { Secondary/degraded upland } \\
\text { forest }\end{array}$ & 1029.65 & 3762.45 & 2408.02 & 482.41 & 3952.87 & 88.38 \\
\hline & Primary peat swamp forest & $-[+]$ & - & 95.24 & 0 & 114.29 & 0 \\
\hline & $\begin{array}{l}\text { Secondary/degraded peat } \\
\text { swamp forest }\end{array}$ & - & - & 0 & 0 & 0 & 0 \\
\hline & Open swamp land & - & - & 0 & 0 & 0 & 0 \\
\hline & Oil palm plantation & 0 & 0 & 963.23 & 3942.16 & 933.44 & 3923.46 \\
\hline & Other nonforest & 564.73 & 1256.70 & 789.66 & 574.28 & 1774.46 & 1001.65 \\
\hline \multirow{7}{*}{$\begin{array}{l}\text { Site } 2(13,605 \\
\text { ha concession) }\end{array}$} & Primary upland forest & \multicolumn{2}{|r|}{ tevo } & \multicolumn{2}{|c|}{0} & \multicolumn{2}{|c|}{0} \\
\hline & $\begin{array}{l}\text { Secondary/degraded upland } \\
\text { forest }\end{array}$ & \multicolumn{2}{|c|}{0} & \multicolumn{2}{|c|}{0} & \multicolumn{2}{|c|}{0} \\
\hline & Primary peat swamp forest & \multicolumn{2}{|c|}{0} & \multicolumn{2}{|c|}{0} & \multicolumn{2}{|c|}{0} \\
\hline & $\begin{array}{l}\text { Secondary/degraded peat } \\
\text { swamp forest }\end{array}$ & \multicolumn{2}{|c|}{$11,419.42$} & \multicolumn{2}{|c|}{5676.48} & \multicolumn{2}{|c|}{5426.29} \\
\hline & Open swamp land & \multicolumn{2}{|c|}{518.62} & \multicolumn{2}{|c|}{1358.77} & \multicolumn{2}{|c|}{766.54} \\
\hline & Oil palm plantation & & & \multicolumn{2}{|c|}{4670.86} & \multicolumn{2}{|c|}{5265.66} \\
\hline & Other nonforest & & & & & & \\
\hline \multirow{7}{*}{$\begin{array}{l}\text { Site } 3(34,000 \\
\text { ha concession })\end{array}$} & Primary upland forest & & & & & & \\
\hline & $\begin{array}{l}\text { Secondary/degraded upland } \\
\text { forest }\end{array}$ & \multicolumn{2}{|c|}{0} & \multicolumn{2}{|c|}{4072.17} & \multicolumn{2}{|c|}{4179.84} \\
\hline & Primary peat swamp forest & \multicolumn{2}{|c|}{753.48} & \multicolumn{2}{|c|}{568.10} & \multicolumn{2}{|c|}{710.19} \\
\hline & $\begin{array}{l}\text { Secondary/degraded peat } \\
\text { swamp forest }\end{array}$ & \multicolumn{2}{|c|}{0} & \multicolumn{2}{|c|}{0} & \multicolumn{2}{|c|}{19.00} \\
\hline & Open swamp land & & & & & & \\
\hline & Oil palm plantation & & & & & & \\
\hline & Other nonforest & & & & & & \\
\hline
\end{tabular}

${ }^{[\dagger]}$ classes that could not be identified during the land-cover analysis because of lack of supporting data

Fig. 3. Land cover change analysis for site 2 shown in three different time periods: (a) 1989 (prior to plantation establishment in 1994); (b) 2001; and (c) 2009.

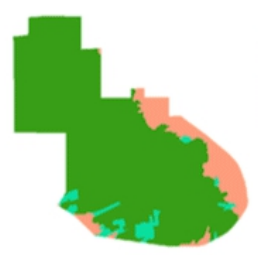

1989

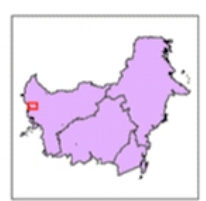

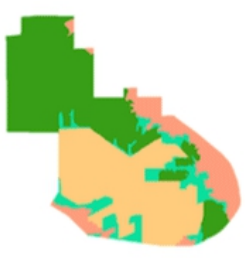

2001

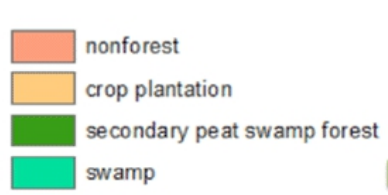

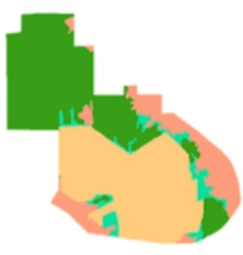

2009

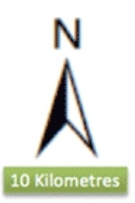

remaining forest areas. All respondent groups at all research sites experienced decreased forest cover, but this was most salient for former landowners and land users; deforestation has adversely affected forestry activities, which are an important component of their livelihoods. As a result, these stakeholders have had to cover much greater distances to collect forest products and prepare their swiddens. In site 3, all groups experienced the effects of shrinking forest cover, particularly former landowners and those living adjacent to plantations. Deforestation led to the siltation of waterways and swamps used as sources of fresh water for domestic needs.

In site 1, decreased forest cover, soil erosion, subsequent siltation, and declining water quality and quantity were perceived to constitute important environmental impacts of plantation development. Respondents living near the plantation in site 1 experienced air pollution because of burning of the oil palm waste, while employees and outgrowers saw soil erosion and sedimentation of rivers as an important environmental problem. Removing original land cover in and around oil palm cultivation areas has eroded soil, particularly in riparian areas where increased water flows 
during the rainy season cause abrasion. Flash floods also damaged the oil estate significantly, making parts of it inaccessible, and thus delaying and reducing harvest.

Fig. 4. Land cover change analysis for site 3 in three time periods (a) 1990 (prior to plantation establishment); (b) 2002 (showing land clearing in Block A); and (c) 2008 (showing land clearing in Block B).

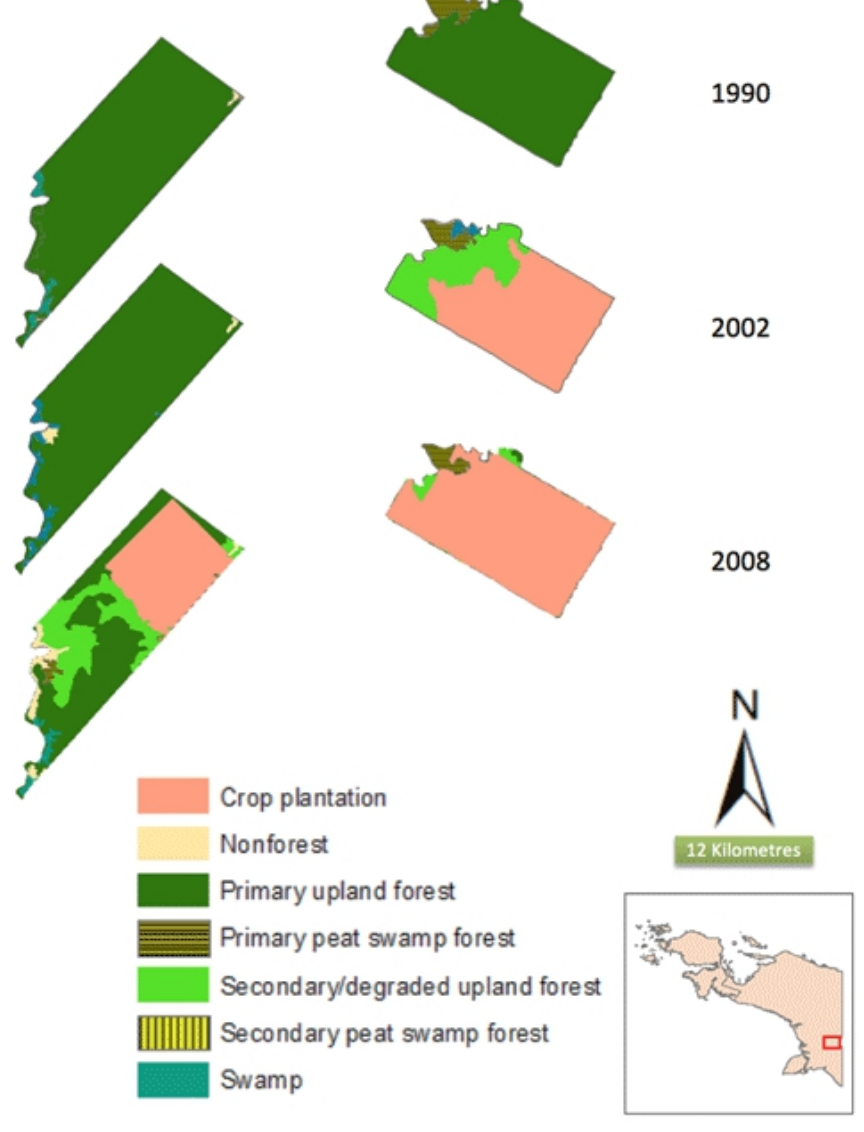

Table 7. Deforestation and oil palm expansion in all sites.

\begin{tabular}{lccc}
\hline \hline Parameter & Site 1 & Site 2 & Site 3 \\
\hline $\begin{array}{l}\text { Net deforestation } \\
\text { Deforestation due to } \\
\text { oil palm }\end{array}$ & 4056.11 ha & 7099.63 ha & $21,804.07$ ha \\
Total oil palm & 4856.90 ha & 5265.66 ha & $20,999.41$ ha \\
$\begin{array}{l}\text { expansion } \\
\% \text { oil palm expansion } \\
\text { that occurs at the } \\
\text { expense of forests }\end{array}$ & $83 \%$ & $94 \%$ & $99 \%$ \\
\hline
\end{tabular}

In site 2, stakeholder groups perceived various environmental impacts, both in type and degree. All respondent groups perceived flash floods leading to declining water quality and quantity and deforestation as important environmental impacts. The destruction of natural drainage caused low-lying areas to become waterlogged. The company tried to remedy the problem by building canals both inside and along the perimeter of the plantation. However, these canals could not handle the massive amounts of water during the rainy season. Besides frequent floods during the rainy season, respondents also experienced worsening water quantity during the dry season. Former landowners and customary users also reported smog from forest fires as one of the most significant and undesirable environmental impacts during plantation establishment. Finally, respondents reported worsening crop pests and various skin diseases.

Table 8. Environmental impacts observed by all stakeholder groups in each research site (\% of respondents reporting issues of concern).

\begin{tabular}{lccc}
\hline \hline Parameter & $\begin{array}{c}\text { Site 1 } \\
(\mathrm{n}=137)\end{array}$ & $\begin{array}{c}\text { Site 2 } \\
(\mathrm{n}=150)\end{array}$ & $\begin{array}{c}\text { Site 3 } \\
(\mathrm{n}=97)\end{array}$ \\
\hline Decreased water quality & $32 \%$ & $50 \%$ & $58 \%$ \\
Decreased water quantity & $18 \%$ & $79 \%$ & $50 \%$ \\
Decreased forest cover & $69 \%$ & $70 \%$ & $53 \%$ \\
Increase in crop pests & $5 \%$ & $22 \%$ & $22 \%$ \\
Air pollution & $7 \%$ & $28 \%$ & $37 \%$ \\
Soil erosion & $53 \%$ & $5 \%$ & $33 \%$ \\
Soil stabilization & $15 \%$ & $23 \%$ & $8 \%$ \\
Increase in human disease & $24 \%$ & $27 \%$ & $31 \%$ \\
Flooding & $0 \%$ & $44 \%$ & $0 \%$ \\
\hline
\end{tabular}

In site 3, respondents perceived water and air pollution as significant environmental effects of oil palm expansion. Because the companies use significant amounts of pesticides and herbicides, they advised workers not to use the river water for daily needs, and instead constructed wells. The neighboring communities and former landowners also expressed concern about air pollution from dust and smoke coming from the plantation and mill site. They mentioned soil erosion as a major problem, particularly in 2009-2010 because of higher rainfall.

\section{Livelihood impacts}

The groups most negatively affected by land use change are former landowners and customary land users (Table 9). They have to walk farther to collect forest products or to open new fields for shifting cultivation. Households relying on forests resources for income and food had to shift to other sources of livelihood. Those involved in logging and sawmill employment abandoned these livelihood activities entirely because of dwindling forest resources. Because of diminishing forest products and services they had to shift to on-farm activities, such as food crop cultivation (for those who still owned land) or off-farm work (e.g. construction). 
Table 9. Perceived livelihood impacts of oil palm plantations according to former landowners and customary users.

\begin{tabular}{|c|c|c|c|c|c|c|c|c|c|}
\hline \multirow[b]{2}{*}{ Local indicator } & \multicolumn{3}{|c|}{ Site $1(n=41)$} & \multicolumn{3}{|c|}{ Site $2(n=60)$} & \multicolumn{3}{|c|}{ Site $3(n=15)$} \\
\hline & negative & $\begin{array}{c}\text { no } \\
\text { impact }\end{array}$ & positive & negative & $\begin{array}{c}\text { no } \\
\text { impact }\end{array}$ & positive & negative & no impact & positive \\
\hline $\begin{array}{l}\text { Time to access forest } \\
\text { products }\end{array}$ & $50 \%$ & $33 \%$ & $17 \%$ & $86 \%$ & $14 \%$ & $4 \%$ & $100 \%$ & $0 \%$ & $0 \%$ \\
\hline $\begin{array}{l}\text { Ease of accessing land for } \\
\text { swiddens }\end{array}$ & $25 \%$ & $44 \%$ & $31 \%$ & $71 \%$ & $27 \%$ & $10 \%$ & $67 \%$ & $33 \%$ & $0 \%$ \\
\hline $\begin{array}{l}\text { Time taken to access } \\
\text { swiddens }\end{array}$ & $42 \%$ & $28 \%$ & $31 \%$ & $9 \%$ & $78 \%$ & $13 \%$ & $67 \%$ & $33 \%$ & $0 \%$ \\
\hline
\end{tabular}

About $47 \%$ of respondents from among customary land users reported negative livelihood changes as a direct result of the land transfer to oil palm (Table 10). Site 3 observed the most negative changes, whereby $86 \%$ of respondents indicated adverse livelihood changes. Respondents attributed these changes to the decline in income from forest products and reduced access to sources of food. About $30 \%$ of respondents indicated mixed livelihood changes. Respondents reporting positive changes following land transfer attributed this largely to improved infrastructure, such as schools, health clinics, or religious centers.

In site 1, despite land loss, most livelihoods improved. However, this was not entirely on account of oil palm, because these households had income from other off- and on-farm activities. Their prior experience with oil palm enabled them to capture opportunities associated with oil palm expansion. They received compensation for communal land taken over by the plantation and received plots of oil palm land in exchange for land with ownership certificates. As the plantation permit gets closer to expiry in September 2012, problems in this site are expected to intensify. Former landowners and customary users are eager to get their land back and are already staking claims. According to local customary law, a ritual ceremony involving appropriate compensation must take place to release any land to be acquired by a company for plantation projects. Because consultation and compensation were not done properly, discontent is rife. The parties tried unsuccessfully to seek resolution on several occasions. In both sites in Papua, compensation, when paid, was given to tribal chiefs, who were expected to distribute the funds among appropriate community members. Internal conflict ensued because of lack of transparency in the distribution of these funds.

In site 2, the company began acquiring land from local communities in 1994 with a promise to establish plasma plantations, roads, and other infrastructure, e.g., schools and religious centers) In addition, the company promised to provide jobs for local residents, offer appropriate compensation for acquired land, and pay for land clearing. After several years, the company has paid wages for land clearing and developed plasma for several communities.
Employment promises were only partially fulfilled, mostly in the form of jobs for unskilled workers. More than half of those losing land to the company experienced a decline in their livelihood, whereas $31 \%$ of respondents indicated some livelihood improvement. Respondents who indicated livelihood improvement were mostly smallholder oil palm growers. Those who reported declining livelihoods pointed mainly to loss of income from the forest and exposure to negative environmental impacts from plantation operations.

In site 3 , only $7 \%$ of respondents experienced positive changes in their livelihoods following plantation expansion. The remaining $93 \%$ of respondents regretted the establishment of oil palm plantations. With 20,000 ha of land occupied by the plantation, their livelihoods declined significantly, mainly because of decreasing opportunities for hunting, fishing, and collection of sago and other forest resources. Even though formal employment on plantations is an option, most people in this group are not able to work consistently because of limited skills and a reluctance to give up traditional ways of life. The employee group of respondents reported a mix of negative and positive implications from oil palm, with the latter dominant: $81 \%$ stated they had to forego former livelihood activities, such as farm-related activities (53\%) and paid labor $(39 \%)$, when seeking formal employment on plantations. In most cases, workers had to reduce their previous livelihood activities because of the heavy work load and long time spent on plantations. Very few people managed to maintain both sets of activities. Other family members have mostly had to generate supplemental income to compensate for the forgone benefits associated with forestry, agricultural, and other livelihood activities.

Most of the positive impacts were attributed to higher income, as well as more regular income flows (Table 11). In site 2, $75 \%$ of workers experienced better livelihood conditions because of palm oil expansion. Most employees in site 2 indicated they can still obtain complementary income from farming, largely because they already had perennial crops such as rubber, which are less labor intensive once established. They also stated the company partially covers their health expenses; however, this benefit is for permanent workers only. Between $50 \%$ and $80 \%$ of workers are hired on a temporary basis and 
Table 10. Perceived social-economic impacts among former landowners and customary users.

\begin{tabular}{|c|c|c|c|c|c|c|c|c|c|c|c|c|}
\hline \multirow[b]{2}{*}{ Variable } & \multicolumn{3}{|c|}{ Site $1(n=41)$} & \multicolumn{3}{|c|}{ Site $2(n=60)$} & \multicolumn{3}{|c|}{ Site $3(n=15)$} & \multicolumn{3}{|c|}{ Average } \\
\hline & negative & $\begin{array}{c}\text { no } \\
\text { impact }\end{array}$ & positive & negative & $\begin{array}{c}\text { no } \\
\text { impact }\end{array}$ & positive & negative & $\begin{array}{c}\text { no } \\
\text { impact }\end{array}$ & positive & negative & $\begin{array}{c}\text { no } \\
\text { impact }\end{array}$ & positive \\
\hline Income level & $16 \%$ & $13 \%$ & $71 \%$ & $32 \%$ & $43 \%$ & $25 \%$ & $88 \%$ & $13 \%$ & $0 \%$ & $29 \%$ & $23 \%$ & $32 \%$ \\
\hline Quality of housing & $15 \%$ & $37 \%$ & $53 \%$ & $31 \%$ & $58 \%$ & $12 \%$ & $38 \%$ & $25 \%$ & $38 \%$ & $27 \%$ & $39 \%$ & $33 \%$ \\
\hline $\begin{array}{l}\text { Quality of social networks of } \\
\text { importance to livelihoods }\end{array}$ & $8 \%$ & $65 \%$ & $32 \%$ & $22 \%$ & $22 \%$ & $56 \%$ & $75 \%$ & $25 \%$ & $0 \%$ & $35 \%$ & $37 \%$ & $29 \%$ \\
\hline Access to food & $3 \%$ & $21 \%$ & $76 \%$ & $9 \%$ & $47 \%$ & $44 \%$ & $100 \%$ & $0 \%$ & $0 \%$ & $37 \%$ & $23 \%$ & $40 \%$ \\
\hline Access to social infrastructure & $42 \%$ & $0 \%$ & $58 \%$ & $8 \%$ & $23 \%$ & $69 \%$ & $13 \%$ & $0 \%$ & $88 \%$ & $21 \%$ & $8 \%$ & $72 \%$ \\
\hline Positive livelihood changes & & $39 \%$ & & & $31 \%$ & & & $0 \%$ & & & $23 \%$ & \\
\hline Mixed livelihood changes & & $61 \%$ & & & $14 \%$ & & & $7 \%$ & & & $30 \%$ & \\
\hline Negative livelihood changes & & $0 \%$ & & & $55 \%$ & & & $93 \%$ & & & $47 \%$ & \\
\hline
\end{tabular}

can lose their jobs at any moment. Their wages are based on work output, and they must work 26 days per month and 8 hours per day to obtain full wages. They lose income if they do not fulfill targets because of sickness or other reasons. The company requires workers to purchase their own tools such as boots, machetes ('parang'), and pull carts, which further erodes official incomes.

Table 11. Perceived livelihood changes for employees.

\begin{tabular}{lcccc}
\hline \hline Variable & $\begin{array}{c}\text { Site 1 } \\
(\mathrm{n}=38)\end{array}$ & $\begin{array}{c}\text { Site 2 } \\
(\mathrm{n}=30)\end{array}$ & $\begin{array}{c}\text { Site 3 } \\
(\mathrm{n}=47)\end{array}$ & Average \\
\hline Increased income & $84 \%$ & $73 \%$ & $60 \%$ & $71 \%$ \\
More reliable income & $63 \%$ & $73 \%$ & $68 \%$ & $68 \%$ \\
Ability to invest in other income & $55 \%$ & $20 \%$ & $21 \%$ & $32 \%$ \\
generating activities & & & & \\
Increase in purchasing power & $32 \%$ & $33 \%$ & $49 \%$ & $39 \%$ \\
Increase in consumption & $32 \%$ & $37 \%$ & $56 \%$ & $43 \%$ \\
Availability of public facilities & $3 \%$ & $40 \%$ & $17 \%$ & $18 \%$ \\
Positive livelihood changes & $32 \%$ & $75 \%$ & $30 \%$ & $46 \%$ \\
Mixed livelihood changes & $53 \%$ & $7 \%$ & $24 \%$ & $28 \%$ \\
Negative livelihood changes & $15 \%$ & $18 \%$ & $46 \%$ & $26 \%$ \\
\hline
\end{tabular}

Respondents from the investing households' group reported mostly positive livelihood impacts because of oil palm development. This group, which only exists in sites 1 and 2 , is made up primarily of migrants who have been residing in the area since the early 1970 s as part of the government transmigration program. Under this program, the government allocated two ha of land for each household head, providing a formal land title. This group attributed the positive impact to higher income, broadening social networks, access to infrastructure, and better housing (Table 12). Negative impacts were associated with concerns over land speculation and the carefree manner with which some communities transfer their land. Similarities were observed between sites 1 and 2, where both plantation companies implemented the outgrower scheme. Most plasma farmers reported an improvement in livelihoods, suggesting the beneficial nature of these schemes.
In site $1,85 \%$ of households claimed to have former land uses, i.e., forest products and agriculture, displaced by oil palm. In terms of forest products, the displaced items include timber and medicinal plants, whereas the agricultural portfolio includes secondary crops, fruit trees, and cassava. Hopes for higher income are the main reasons behind the change from former land uses and livelihood activities to oil palm. After 10 to 15 years, more than $85 \%$ of plasma farmers have repaid loans taken to establish smallholder plantations. Now the land and oil palm plots belong to them, and ownership certificates can be used to secure bank loans for further business ventures. Negative impacts were primarily observed in plasma areas near the nucleus estate, mostly in the form of conflicts with former landowners demanding the return of their land. These conflicts occur because the current plasma holders received their land through the government-sponsored transmigration program, which ignores local customary norms and realities. The Papuans who are traditional landowners now demand the return of their land. The issue is difficult to resolve and numerous mediation attempts by local government institutions have proven unsuccessful. The Papuans perceive the government as biased toward transmigrants. They also resent the incomes transmigrants gain from oil palm, which Papuans think are rightfully theirs. In the Manokwari area, where most of the plasma holders are transmigrants, customary landowners currently receive three billion rupiah (US\$300,000) to compensate for the entire area of lost land.

In site 2, plasma plantations were initiated in 1997, while independent growers began their plantations in 1999. More than $63 \%$ of oil palm cultivated by investing households in this area displaced former land uses. Former land uses displaced by oil palm include rubber plantations, pineapple groves, secondary forests, and fallow. Higher economic profitability is also the main reason for the shift of livelihood activities to oil palm. The higher income level among investing households shows some benefits for smallholders; plasma is perceived to be more beneficial because the plantation company does most of the management. Although monthly income generated from these activities varies, most 
Table 12. Attributes to livelihood impact for investing households group.

\begin{tabular}{|c|c|c|c|c|c|c|c|c|c|}
\hline \multirow[b]{2}{*}{ Variable } & \multicolumn{3}{|c|}{ Site $1(n=30)$} & \multicolumn{3}{|c|}{ Site $2(n=30)$} & \multicolumn{3}{|c|}{ Average } \\
\hline & negative & no impact & positive & negative & no impact & positive & negative & no impact & positive \\
\hline Income level & $14 \%$ & $32 \%$ & $55 \%$ & $21 \%$ & $0 \%$ & $79 \%$ & $18 \%$ & $16 \%$ & $67 \%$ \\
\hline Access to food & $14 \%$ & $41 \%$ & $45 \%$ & $11 \%$ & $29 \%$ & $61 \%$ & $12 \%$ & $35 \%$ & $53 \%$ \\
\hline $\begin{array}{l}\text { Quality of social networks of } \\
\text { importance to livelihoods }\end{array}$ & $13 \%$ & $39 \%$ & $48 \%$ & $0 \%$ & $21 \%$ & $79 \%$ & $7 \%$ & $30 \%$ & $64 \%$ \\
\hline Quality of housing & $22 \%$ & $22 \%$ & $57 \%$ & $7 \%$ & $52 \%$ & $41 \%$ & $15 \%$ & $37 \%$ & $49 \%$ \\
\hline Access to social infrastructure & $17 \%$ & $39 \%$ & $44 \%$ & $0 \%$ & $25 \%$ & $75 \%$ & $9 \%$ & $32 \%$ & $60 \%$ \\
\hline $\begin{array}{l}\text { Ease of accessing new } \\
\text { agricultural land }\end{array}$ & $27 \%$ & $32 \%$ & $41 \%$ & $80 \%$ & $16 \%$ & $4 \%$ & $54 \%$ & $24 \%$ & $23 \%$ \\
\hline
\end{tabular}

respondents reported it as satisfactory. Some have retained parts of their former livelihood activities and therefore are able to obtain additional income.

However, not all investing households have secured immediate returns. For independent growers, the earlier years were most difficult because they had to forgo other livelihood activities to maintain plantations. Regardless of this burden in the early years of oil palm establishment, new families continue to invest in oil palm as independent growers.

Investing households in site 2 are better off than in site 1. Prior to oil palm, most were cultivating cash crops, e.g., rubber, while others were also involved in timber extraction. When forest resources became unavailable because of plantation development, they responded by investing in oil palm plots. These households possessed the capital necessary for up-front investment, enabling them to partner with oil palm companies to meet company production targets. Positive impacts were also attributed to road construction, which has improved access to nearby urban areas and markets for agricultural produce. However, respondents indicated that oil palm plantations have attracted other investors, resulting in increasing land prices and a corresponding difficulty in expanding their plantation area.

Affected neighbors, i.e., the adjacent communities not directly participating in oil palm development but exposed to its impacts, reported similar social and economic effects in all research sites (Table 13). A total of 93 respondents interviewed indicated similar effects associated with the oil palm expansion. Because flooding determined access to nearby markets, respondents perceived flash floods as an important factor affecting their social or economic life. Water pollution due to extensive use of fertilizers and pesticides on the plantation estate was also perceived as an important factor that mostly affected the quality of drinking water. Respondents indicated that employment opportunities in oil palm and road construction have positively affected their socioeconomic conditions. Off-farm business such as restaurants, repair shops, and transportation are in high demand because of oil palm plantations.
Table 13. Perceived social and economic effects associated with the oil palm expansion.

\begin{tabular}{|c|c|c|c|c|}
\hline Variable & $\begin{array}{c}\text { Site } 1 \\
(\mathrm{n}=28)\end{array}$ & $\begin{array}{c}\text { Site } 2 \\
(\mathrm{n}=30)\end{array}$ & $\begin{array}{l}\text { Site } 3 \\
(\mathrm{n}=35)\end{array}$ & Average \\
\hline $\begin{array}{l}\text { Loss of customary access to forest } \\
\text { products }\end{array}$ & $14 \%$ & $77 \%$ & $29 \%$ & $40 \%$ \\
\hline $\begin{array}{l}\text { Loss of customary access to } \\
\text { cropland }\end{array}$ & $0 \%$ & $53 \%$ & $11 \%$ & $22 \%$ \\
\hline $\begin{array}{l}\text { Loss of customary access to water } \\
\text { resources }\end{array}$ & $4 \%$ & $37 \%$ & $26 \%$ & $22 \%$ \\
\hline Water pollution & $43 \%$ & $70 \%$ & $83 \%$ & $65 \%$ \\
\hline Air pollution & $0 \%$ & $30 \%$ & $89 \%$ & $40 \%$ \\
\hline $\begin{array}{l}\text { Increased incidence of human or } \\
\text { crop pests/disease }\end{array}$ & $18 \%$ & $30 \%$ & $69 \%$ & $39 \%$ \\
\hline Loss of primary crop land & $29 \%$ & $10 \%$ & $14 \%$ & $18 \%$ \\
\hline Displacement/resettlement & $11 \%$ & $0 \%$ & $3 \%$ & $5 \%$ \\
\hline Increased incidence of floods & $64 \%$ & $87 \%$ & $54 \%$ & $68 \%$ \\
\hline $\begin{array}{l}\text { Employment opportunities in oil } \\
\text { palm plantation }\end{array}$ & $36 \%$ & $27 \%$ & $60 \%$ & $41 \%$ \\
\hline $\begin{array}{l}\text { Transportation and access to } \\
\text { urban areas }\end{array}$ & $46 \%$ & $7 \%$ & $89 \%$ & $47 \%$ \\
\hline
\end{tabular}

Conflict was one of the most important and widespread social effects observed in all three sites. Conflicts over land between communities are considered minor, whereas conflicts between communities and companies over compensation for land and labor are considered to be more serious. Another form of conflict takes place between traditional owners and non-native communities, i.e., migrants. Prioritizing control over traditional claims, the government routinely allocates the local community land for transmigration and development. This causes conflict that continues long after the establishment of transmigration settlements.

\section{DISCUSSION: IMPLICATIONS OF OIL PALM DEVELOPMENT FOR BIOFUELS}

The analysis of land cover changes in concession areas and household survey data from three selected sites in West Kalimantan, West Papua, and Papua has several implications during oil palm plantation establishment that need careful consideration. 


\section{Uneven economic benefits}

Oil palm plantations generate uneven economic benefits at the cost of significant environmental losses. As shown in the previous section, the economic livelihood gains for some stakeholders can be substantial, although not equitably distributed. In all three sites, the employees of oil palm plantations reported positive livelihood changes mainly because of salaried income and other job-related benefits, although employment terms had their drawbacks. In sites 1 and 2, the households investing in oil palm holdings all reported beneficial livelihood outcome as well. However, not all are able to raise the capital to develop smallholder oil palm. Therefore, in sites 1 and 2 this remains a livelihood option for the privileged; in site 3 , in Boven Digoel, the investing households' group does not exist at all.

\section{More established plantations correlate to stronger benefits}

The variation between the sites in terms of reported positive changes correlates with the history of oil palm in each site, stakeholder familiarity with oil palm management practices, and their oil palm-related skills. West Kalimantan has a comparatively long history of oil palm plantation development; the positive report about livelihood changes among the employees and investing households in site 2 is thus more uniform, whereas negative feedback is less pronounced. West Papua also has been exposed to oil palm plantation estates. However, Papua's more remote location and limited interaction with other oil palm centers results in limited management skills; they have less success in generating benefits. In site 3 in Papua, oil palm is a very new crop found in a very remote location. It is therefore likely the local population has not yet developed the knowledge, skills, and means to manage plantations effectively.

\section{Benefits come with significant environmental cost}

Employee and investing household benefits are generated at significant environmental cost through deforestation and secondary impacts such as air and water pollution. In all three sites, plantation concessions were covered with primary and secondary forest, leading to the clearing of about 70,000 ha of forest in exchange for economic benefits to a relatively circumscribed set of stakeholders. Our findings also indicate significant problems with air pollution, water pollution, soil erosion, waterway siltation, and flooding. Similar studies corroborate these findings (Dudgeon et al. 2006, Danielsen et al. 2008, Fitzherbert et al. 2008, Hartemink 2006, Henson 2003, World Bank 2010).

\section{Winners and losers}

Although plantation employees and investing households have benefited from oil palm, there are losers as well as winners. Customary land users and former landowners are among the most negatively affected by plantation expansion because they are often unfamiliar with oil palm as a crop, cannot develop oil palm smallholdings, and possess neither the necessary knowledge nor skills to obtain plantation employment (McCarthy 2010, Colchester and Chao 2011). The process of land transfer to plantation developers is a major problem that often leaves customary land users and former landowners on the losing end. Most of the time, government agencies simply issue concession permits; they emphasize the need for prior community acceptance of plantation investment plans, but let the companies and communities negotiate the level and nature of compensation. Companies often claim exaggerated benefits of plantation development for local communities. They also tend to focus on village elite during negotiations causing problems of representation and elite capture. Government authorities should be aware of these problems and participate in negotiations to ensure that agreements are fair, not one-sided. Although affected neighbors indicate they have also experienced positive impacts from the presence of plantations, we found this to be true for only a small number of people. The main concerns of this group relate to plantation expansion plans and the potential for more reductions of their customary land.

\section{Companies clear land years before developing plantations}

The economic gains accrue at the expense of weak rule of law (Kartodihardjo and Supriono 2000, Wakker 2005, Reinhardt et al. 2007). The plantation companies in three selected sites have acquired concession areas that have taken several years, in some cases decades, to be partially developed into plantations. Yet timber extraction has proceeded more rapidly. This illustrates the broad tendency of plantation investors in Indonesia to acquire large areas of forested land at once for economies of scale, long-term planning, and investment risk mitigation.

Historically, oil palm companies in Indonesia have developed plantations on just a fraction of the land they have been given. For instance, Sumatra and Kalimantan islands combined have more than 11 million ha of concessions to be developed into plantations. However, as of 2010 , less than half of this area had been developed (Slette and Wiyono 2011); others areas, allegedly developed, have actually been abandoned.

Plantation development commonly lags for years or decades, but the removal of forest cover is considerably faster (Koh and Wilcove 2008, McCarthy and Cramb 2009; A. Casson, L. Taccioni, and K. Deddy, unpublished manuscript). Plantation companies do this to generate up-front capital, offset plantation investment costs, secure land immediately for future expansion, or simply to benefit from timber only (Casson et al. 2007, Hunt 2010, Schwarz 2010).

\section{Land clearing has direct and indirect environmental impacts}

The clearance of forests not only destroys forest cover, it also leads to a range of associated indirect environmental impacts. 
Although some of these occur naturally, with or without the presence of plantations, many adverse impacts are clearly due to poor oil palm plantation practices. This raises the question of whether the concerned companies have implemented environmental impact assessment (EIA) guidelines effectively.

\section{Targets for biofuel production and feedstock cultivation unreached}

Clearly, only a small fraction of government targets for biofuel production and feedstock cultivation has been reached. This raises questions about the feasibility of grand policies that are still in effect. The national biofuel and plantation area targets were originally introduced to meet domestic needs for renewable energy. The national taskforce for development of biofuels set the target of four million ha of oil palm plantations to support the production of 16 million tons of biodiesel by 2015 (Ministry of Energy and Mineral Resources 2006). As of 2010, only 353,357 metric tons of biodiesel were produced; this required 67,829 ha of oil palm plantations (Table 14), less than $2 \%$ of the planned area target (Slette and Wiyono 2010). This raises serious questions about the direction of Indonesia's biofuel policy and calls for an assessment of conditions under which better outcomes could be achieved.

Table 14. Domestic consumption of biosolar.

\begin{tabular}{cccc}
\hline \hline Year & $\begin{array}{c}\text { Consumption of } \\
\text { Biosolar B-5 (MT) } \\
{[\dagger]}\end{array}$ & $\begin{array}{c}\text { CPO requirement } \\
\left(\text { MT) }{ }^{[\dagger]}\right.\end{array}$ & $\begin{array}{c}\text { oil palm plantation } \\
\left(\text { ha) }{ }^{[\S]}\right.\end{array}$ \\
\hline 2006 & 192.078 & 9.901 & 3.300 \\
2007 & 491.689 & 25.345 & 8.448 \\
2008 & 824.052 & 42.477 & 14.159 \\
2009 & 2122.331 & 109.399 & 36.466 \\
2010 & 3947.633 & 203.486 & 67.829 \\
\hline
\end{tabular}

Source: ${ }^{[\dagger]}$ Pertamina $2011 ;{ }^{[\neq]}$and ${ }^{[\S]} 1$ metric ton (MT) crude palm oil (CPO) equals 0.97 MT of fatty acid methyl ester (FAME) or 8 MT of fresh fruit bunches (FFB); average productivity of oil palm plantation is 15 tons FFB per hectare.

\section{Land allocation regulations not implemented}

The analysis of concession allocation for oil palm in selected sites, and more broadly in Indonesia, has also exposed contradictions between land allocation regulations for oil palm and their implementation. The Ministry of Forestry and Ministry of Agriculture regulations stipulate that a plantation company may be granted up to 100,000 ha and 200,000 ha of land outside and inside of Papua, respectively, but that the land must be released in stages. Almost invariably this requirement is ignored and large areas of land are given at once.

In many parts of Indonesia, particularly in Papua, government planners often perceive forest as "idle" or unoccupied land that must be "optimized" for national development (AgroIndonesia 2010). Our findings clearly indicate that local communities have developed multiple uses for forested zones and significant portions of their livelihood portfolios depend on continued availability of these forests.

The point of departure to minimize these negative trade-offs must begin with a shift from seeing forests as unproductive idle land to a vision of forests as occupied, supportive of rural livelihoods, and providers of important environmental services. This need not impede the flow of economic benefits from oil palm. Plantation development should continue, but it should focus on nonforest land, which is abundant in Indonesia. It should also involve smaller concession areas and release land gradually to allow for more effective monitoring of plantation development and EIA management practices.

\section{CONCLUSION: GOVERNING OIL PALM IMPACTS}

By assessing the environmental and socioeconomic impacts of palm plantations associated with bioenergy production in Indonesia, we have examined options to minimize the negative impacts while maximizing the potential for social and economic benefits. We present several recommendations for government, industry leaders, and civil society organizations:

\section{Channel future development into nonforest land}

Most negative environmental trade-offs stem from the fundamental undervaluation of the forest in Indonesia as an economic asset. Voluntary or mandatory carbon sequestration schemes such as REDD (Reduced Emissions from Deforestation and Degradation) may make it possible in future for greater economic appreciation of forest as a nonextractive resource. For this option to succeed, government planners must take steps to reconcile competing land use regimes in Indonesia and channel most future plantation development into nonforest land. This requires extensive capacity building and applied work to formulate commonly agreed criteria and indicators for degraded land in Indonesia, identifying degraded nonforest land for plantation investments, and offering appropriate incentives to encourage plantation investors to use make of degraded lands.

\section{Map extent and distribution of degraded land}

At least five different terms in Indonesia currently denote degraded land (lahan kritis, lahan terlantar, lahan tidur, lahan kosong, alang-alang). To complicate matters further, each term encompasses imprecise degrees of severity. Consequently, estimates of the total area of degraded land vary from 30 to 70 million ha. A commonly accepted definition of degraded land, accompanied by clearly specified criteria and indicators, is thus a critical issue. With such a definition in place, the National Land Use Agency, Ministry of Forestry, and Ministry of Agriculture need to work with counterpart agencies in districts and provinces to map and assess the extent and distribution of degraded land in Indonesia. 


\section{Assess life-cycle costs of plantations}

Once more is known about the extent, location, and availability of degraded land for investment, the Ministry of Finance and the National Investment Board need to work with other relevant government agencies to assess necessary incentives for stimulating use of this land for economic purposes. Still relatively little is known about the actual financial and technical inputs needed to establish productive plantation estates on degraded land. Even less is known about how these costs evolve over the life cycle of oil palm plantations. More research is needed in this area to enable government policy makers to understand these issues better and structure appropriate incentives.

\section{Make deforestation the exception to the rule}

It will not always be possible to avoid deforestation in the development of oil palm plantations. After all, it is legal in Indonesia to allocate areas within the Conversion Forest Zone for clearing. However, deforestation should be an exception rather than the rule. Greater care should be taken to prioritize the use of extensive areas of nonforest land. In this context, it is encouraging that the Government of Indonesia has recently taken steps to limit the release of forested land for plantations, instead encouraging investors to use land without forest cover (Kompas 2011).

\section{Enforce regulations and standards}

Government authorities must also ensure that companies adhere to relevant legal, environmental, and management standards. This will not be easy because poor law enforcement is a recurring problem in the plantations sector leading to widespread infractions. Most oil palm plantations in Central Kalimantan Province are technically illegal because they either do not possess the plantation business license (HGU, 'Hak Guna Usaha') or have not secured the permit from the Ministry of Forestry in Jakarta for the release of forested land for clear-cuts (Kompas 2010b). At the very least, stricter checks of EIA implementation should be emphasized to support the current two-year moratorium on forest conversion.

\section{Monitor and mediate community-company negotiations more actively}

Given livelihood changing implications of oil palm for customary communities and frequent conflict, plantation investments must be built on legally binding contracts between investors and local community landowners. This means that local government agencies must monitor and mediate community-company negotiations of land transfer more actively. Once negotiations are successfully completed, the government should release the land gradually, making the availability of additional land for plantations contingent upon satisfactory development of oil palm on the first concession. This will reduce the incentives for timber- oriented business, land banking, and speculation, encouraging participation by legitimate oil palm plantation entrepreneurs.

\section{Adhere to industry standards}

Oil palm sector supervisory organizations such as GAPKI (Indonesian Association of Oil Palm Companies) should also purse broader adherence and implementation of relevant codes of conduct or industry standards to improve plantation management practices among oil palm growers. The most readily available mechanisms are the recently introduced ISPO (Indonesia Sustainable Palm Oil) and RSPO (Roundtable on Sustainable Palm Oil) standards. Serious implementation of either standard should help plantation companies progress significantly toward sustainable plantation practices.

\section{Monitor enforcement of labor regulations}

In terms of socioeconomic benefits, oil palm plantations undoubtedly improve income among certain groups of stakeholders. The plantations also generate opportunities for employment and lead to improved public infrastructure. However, in many cases, oil palm plantations fail to deliver these benefits to a sufficiently large spectrum of actors. Those benefitting most are individuals with some prior experience, knowledge, or skills associated with oil palm, cash crops, or other plantations estates. Those who should gain the most, for example, unskilled workers, local landowners, and remote indigenous communities, are unable to reap significant benefits. Unskilled workers receive minimal compensation and must seek complementary income-generating activities on their own. Local landowners end up with a shrinking communal land base, limited compensation for land released for plantations, increasing time and labor investment needed to collect forest resources, and very few plantations jobs. It is imperative, therefore, that government institutions and civil society organizations push for better monitoring and enforcement of existing labor regulations in the plantation sector.

\section{Strengthen customary land rights}

Among key unresolved issues in Indonesia's oil palm sector is the lack of legal recognition of customary land rights. The failure to recognize the traditional land use/ownerships system results in persistent conflicts. Customary landowners in all research sites are mostly native communities dependent on forests and other natural resources for their livelihoods, and therefore unaccustomed to intensive farming practices. Inability to adapt to the changing legal and economic environment renders these groups susceptible to negative impacts of oil palm development, e.g., economic marginalization and damage to resources upon which their livelihoods depend. As a result, it is critical that the Ministries of Forestry, Agriculture, and Land Use Planning produce options to strengthen customary land rights in Indonesia. This is important not only for oil palm but also for REDD and other economic sectors and conservation initiatives. 
Responses to this article can be read online at: http://www.ecologyandsociety.org/vol17/iss 1/art25/ responses/

\section{Acknowledgments:}

This paper has been produced with the financial assistance of the European Union, under a project entitled, 'Bioenergy, sustainability and trade-offs: Can we avoid deforestation while promoting bioenergy?' Additional funding were also provided by CGIAR System wide on Collective Action and Property Rights (CAPRi) and Cordaid. The objective of the project is to contribute to sustainable bioenergy development that benefits local people in developing countries, minimizes negative impacts on local environments and rural livelihoods, and contributes to global climate change mitigation. The project is managed by Center for International Forestry Research and implemented in collaboration with the Council on Scientific and Industrial Research (South Africa), Joanneum Research (Austria), the Universidad Autónoma de México, and the Stockholm Environment Institute. The views expressed herein can in no way be taken to reflect the official opinion of the European Union and other donors. The authors would like to thank our project partners: Gusti Z. Anshari of Center for Wetlands People and Biodiversity of Tanjungpura University in Pontianak, West Kalimantan; Max Tokede of Papua State University in Manokwari, West Papua;Barnabas F Sedik of District Forestry Office of Boven Digoel, Papua and Habel Waridjo of District Agriculture Office of Boven Digoel, Papua for their kind collaboration on the project. We are also grateful to all staff affiliated with these institutions, who have taken part in field surveys, and to respondents from communities and oil palm companies. The authors would also like to thank the reviewers, especially Andrew Wardell, Director of CIFOR Forests and Governance Programme, Laura German and George Schoneveld for their candid assessment of earlier drafts of this paper.

\section{LITERATURE CITED}

AgroIndonesia. 2010. Tak Mudah Bangun 'Food Estate'. [It is not easy to establish food estates]. AgroIndonesia, 24 March. [online] URL: http://agroindonesia.co.id/2010/03/24/tak-mudahbangun-\%E2\%80\%98food-estate\%E2\%80\%99/

Basiron, Y. 2007. Palm oil production through sustainable plantations. European Journal of Lipid Science Technology 109:289-295. http://dx.doi.org/10.1002/ejlt.200600223

Beaton, C., and L. Lontoh. 2010. Lessons learned from Indonesia's attempts to reform fossil-fuel subsidies. International Institute for Sustainable Development, Winnipeg, Manitoba, Canada.

Beyond Petroleum. 2010. BP statistical review of world energy. British Petroleum, London, UK. [online] URL: http:// www.bp.com/liveassets/bp internet/globalbp/globalbp uk english/ reports and publications/statistical energy review 2008/STAGING/ local assets/2010 downloads/statistical review of world en ergy full report 2010.pdf

Biodiesel Magazine Editorial Staff. 2010. Global biodiesel production and market report. Biodiesel Magazine, 01 September. [online] URL: http://www.biodieselmagazine.com/ articles/4447/global-biodiesel-production-and-market-report

Bringezu, S., H. Schutz, M. O’Brien, L. Kauppi, R. W. Howarth, and J. McNeely. 2009. Towards sustainable production and use of resources: assessing biofuels. United Nations Environment Programme, Nairobi, Kenya.

Bromokusumo, A. K. 2009. Indonesia: biofuels annual report 2009. USDA Foreign Agricultural Service, Washington, D. C., USA. [online] URL: http://gain.fas.usda.gov/Recent\%20G AIN\%20Publications/General\%20Report Jakarta Indonesia 6-1-2009.pdf

Bromokusumo, A. K., and J. P. Slette. 2010. Indonesia: oilseeds and products 2010. USDA Foreign Agricultural Service, Washington, D.C., USA. [online] URL: http://gain.f as.usda.gov/Recent $\% 20 \mathrm{GAIN} \% 20 \mathrm{Publications} /$ Oilseeds $\% 20$ and $\%$ 20Products\%20Annual Jakarta Indonesia 3-18-2010.pdf

Brown, E., and M. Jacobson. 2005. Cruel oil: how palm oil harms health, rainforest and wildlife. Center for Science in the Public Interest, Washington, D.C., USA.

Bunyamin, B. 2008. Dampakpengembangan PIR kelapa sawit terhadap perekonomian regional Kalimantan Barat. [Impacts of oil palm plantations on the regional economy of West Kalimantan region]. Untan Press, Pontianak, Indonesia.

Business Wire. 2007. Biofuel goes big with Indonesia's \$12 billion investments including over $\$ 5$ billion from China. Business Wire, 12 January. [online] URL: http://www.busine sswire.com/news/home/20070112005168/en/Biofuel-BigIndonesias-12-Billion-Investments-Including

Caroko, W., H. Komarudin, K. Obidzinski, and P. Gunarso. 2011. Policy and institutional frameworks for the development of palm oil-based biodiesel in Indonesia. Working Paper No. 62. Center for International Forestry Research, Bogor, Indonesia.

Casson, A. 2000. The hesitant boom: Indonesia's oil palm subsector in an era of economic crisis and political change. Occasional Paper No. 29. Center for International Forestry Research, Bogor, Indonesia.

Casson, A. 2002. The political economy of Indonesia's oil palm sub-sector. Pages 221-245 in C. J. P. Colfer and I. A. P. Resosudarmo, editors. Which way forward? People, forests and policy making in Indonesia. Resources for the Future, Washington, D.C., USA.

Casson, A., L. Tacconi, K. Deddy. 2007. Strategies to reduce carbon emissions from the oil palm sector in Indonesia. 
Working Paper No. 62. Center for International Forestry Research, Bogor, Indonesia.

Colchester, M. 2010. Land acquisition, human rights violations, and indigenous peoples on the palm oil frontier. Forest Peoples Programme, Moreton-in-Marsh, UK.

Colchester, M., and S. Chao, editors. 2011. Oil palm expansion in South East Asia: trends and implications for local communities and indigenous peoples. Forest Peoples Programme, Moreton-in-Marsh, UK.

Colchester, M., N. Jiwan, Andiko, M. Sirait, A. Y. Firdaus, A. Surambo, and H. Pane. 2006. Promised land: palm oil and land acquisition in Indonesia: implications for local communities and indigenous peoples. Forest Peoples Programme and Perkumpulan Sawit Watch, Moreton-inMarsh, UK and Bogor, Indonesia. [online] URL: http://www. forestpeoples.org/sites/fpp/files/publication/2010/08/promisedlandeng. $\underline{\mathrm{pdf}}$

Cotula, L., N. Dyer, and S. Vermeulen. 2008. Fuelling exclusion? The biofuels boom and poor people's access to land. Food and Agriculture Organization and International Institute for Environment and Development, London, UK.

Danielsen, F., H. Beukema, N. D. Burgess, F. Parish, C. A. Brühl, P. F. Donald, D. Murdiyarso, B. Phalan, L. Reijnders, M. Struebig, and E. B. Fitzherbert. 2008. Biofuel plantations on forested lands: double jeopardy for biodiversity and climate. Conservation Biology 23(2):348-358. http://dx.doi.o rg/10.1111/j.1523-1739.2008.01096.x

Dillon, H. S., T. Laan, and H. S. Dillon. 2008. Biofuel at what cost? Government support for ethanol and biodiesel in Indonesia. Global Subsidies Initiative-International Institute for Sustainable Development, Geneva, Switzerland.

Dinas Perkebunan Kalimantan Barat (Disbun Kalbar). 2010. Perkembangan perizinan perusahaan perkebunan besar di Kalimantan Barat (keadaan s/d Desember 2009). [Development of large-scale estate crop plantation companies in West Kalimantan province as of December 2009]. Estate Crops Agency of West Kalimantan Province, Pontianak, Indonesia.

Down To Earth. 2007. New investment law is not pro-poor. Down to Earth, No. 73 May. [online] URL: http://dte.gn.apc. org/73.pdf

Dudgeon, D., A. H. Arthington, M. O. Gessner, Z.-I. Kawabata, D. J. Knowler, C. Lévêque, R. J. Naiman, A.-H. Prieur-Richard, D. Soto, M. L. J. Stiassny, and C. A. Sullivan. 2006. Freshwater biodiversity: importance, threats, status, and conservation challenges. Biological Reviews of the Cambridge Philosophical Society 81:163-182. http://dx.doi.org/10.1017/ S1464793105006950
Emerging Markets Online. 2008. Biodiesel 2020: global market survey, feedstock trends and forecasts. Emerging Markets Online, Houston, Texas, USA. [online] URL: http:// www.emerging-markets.com/biodiesel/

European Union (EU). 2006. An EU strategy for biofuels: communication from the Commission. European Commission, Brussels, Belgium.

Fargione, J., J. Hill, D. Tilman, S. Polasky, and P. Hawthorne. 2008. Land clearing and the biofuel carbon debt. Science 319 (5867):1235-1238. http://dx.doi.org/10.1126/science.1152747

Feintrenie, L., W. K. Chong, and P. Levang. 2010. Why do farmers prefer oil palm? Lessons learnt from Bungo district, Indonesia. Small-Scale Forestry 9(3):379-396. http://dx.doi.o $\mathrm{rg} / 10.1007 / \mathrm{s} 11842-010-9122-2$

Fitzherbert, E. B., M. J. Struebig, A. Morel, F. Danielsen, C. A. Brühl, P. F. Donald, and B. Phalan. 2008. How will oil palm expansion affect biodiversity? Trends in Ecology \& Evolution 23(10):538-545. http://dx.doi.org/10.1016/j.tree.20 $\underline{08.06 .012}$

Food and Agriculture Organization of the United Nations (FAO). 2008a. Biofuels: prospects, risks and opportunities. FAO, Rome, Italy.

Food and Agriculture Organization of the United Nations (FAO). 2008b. Bioenergy, food security and sustainability: towards an international framework. Paper presented at the High-Level Conference on World Food Security: The Challenges of Climate Change and Bioenergy, 3-5 June, FAO, Rome, Italy. [online] URL: http://www.fao.org/fileadmin/use $\underline{\mathrm{r} \text { upload/foodclimate/HLCdocs/HLC08-inf-3-E.pdf }}$

Food and Agricultural Policy Research Institute (FAPRI). 2010. FAPRI 2010 U.S. and World Agricultural Outlook. FAPRI, Iowa State University, Ames, Iowa, USA. [online] URL: http://www.fapri.iastate.edu/outlook/2010/

Friends of the Earth Europe (FoE). 2010. Too green to be true: IOI Corporation in Ketapang District, West Kalimantan. Milieudefensie and Friends of the Earth Europe, Brussels, Belgium. [online] URL: http://www.foeeurope.org/publicatio ns/2010/Too_Green_to_be_True0310.pdf

Gibbs, H. K., A. S. Ruesch, F. Achard, M. K. Clayton, P. Holmgren, N. Ramankutty, and J. A. Foley. 2010. Tropical forests were the primary sources of new agricultural land in the 1980s and 1990s. Proceedings of the National Academy of Sciences of the United States of America 107 (38):16732-16737. http://dx.doi.org/10.1073/pnas.0910275107

Gingold, B. 2010. Degraded land, sustainable palm oil, and Indonesia's future. World Resources Institute, Washington, D. 
C., USA. [online] URL: http://www.wri.org/stories/2010/07/ degraded-land-sustainable-palm-oil-and-indonesias-future

Hallam, D. 2009. International investments in agriculture production. Pages 27-38 in M. Kugelman and S. L. Levenstein, editors. Land grab? The race for the world's farmland. Woodrow Wilson Center for Scholars, Washington, D.C., USA.

Hartemink, A. E. 2006. Soil erosion: perennial crop plantations. Pages 1613-1617 in R. Lal, editor. Soil Science. Taylor \& Francis, London, UK.

Henson, I. E. 2003. Oil palm: can it substitute the tropical rainforest? Planter 79:437-450.

Hoh, R. 2009. Malaysia: biofuels annual report 2009. USDA Foreign Agricultural Service, Washington, D.C., USA. [online] URL: http://gain.fas.usda.gov/Recent\%20GAIN\%20 Publications/General\%20Report Kuala\%20Lumpur Malays ia_6-12-2009.pdf

Hunt, C. 2010. The costs of reducing deforestation in Indonesia. Bulletin of Indonesian Economic Studies 46 (2):187-192. http://dx.doi.org/10.1080/00074918.2010.503563

Indonesia Forest Climate Alliance (IFCA). 2008. Reducing emissions from deforestation and forest degradation in Indonesia. The Ministry of Forestry, Jakarta, Indonesia.

International Centre for Trade and Sustainable Development (ICTSD). 2008. Biofuel production, trade and sustainable development: policy discussion paper. ICTSD, Geneva, Switzerland.

Ismail, M., and A. Rossi. 2010. A compilation of bioenergy sustainability initiatives. Food and Agriculture Organization of the United Nations, Rome, Italy.

Jelsma I., K. Giller, and T. Fairhurst. 2009. Smallholder oil palm production systems in Indonesia: lessons from the NESP Ophir Project. Report by the Plant Sciences Group, Wageningen University, Wageningen, The Netherlands.

Kaiser, E. 2011. Fuel subsidies, South East Asia's 'opium' habit, hard to break. Manila Bulletin, 31 May. [online] URL: http://www.mb.com.ph/articles/320579/fuel-subsidies-southeast-asias-opium-habit-hard-break

Kartodihardjo, H., and S. Supriono. 2000. The impact of sectoral development on natural forest conversion and degradation: the case of timber and tree crop plantations in Indonesia. Occasional Paper No. 26(E). Center for International Forestry Research, Bogor, Indonesia.

Koh, L. P., and D. S. Wilcove. 2008. Is oil palm agriculture really destroying tropical biodiversity? Conservation Letters 1:60-64. http://dx.doi.org/10.1111/j.1755-263X.2008.00011.x
Kompas. 2010a. 1,7 Juta hektar sawit di lahan gambut. [1.7 million ha of oil palm plantation in peatland]. Kompas, 9 September. [online] URL: http://nasional.kompas.com/read/2 $\underline{010 / 09 / 09 / 02453534 /}$

Kompas. 2010b. Perkebunan Sawit Tanpa Izin Marak. [Oil palm plantations without permits rife]. Kompas, 22 February. [online] URL: http://female.kompas.com/read/2010/02/22/03 254493/perkebunan.sawit.tanpa.izin.marak

Kompas. 2011. Izin Pelepasan Hutan untuk Perkebunan Dihentikan. [Release of the state forestland for plantations ceased]. Kompas, 13 July.

Lacey, T. 2009. Biofuels: Indonesian dilemma. Asia Sentinel, 30 January. [online] URL: http://www.asiasentinel.com/index. php?option=com_content $\&$ task $=$ view $\&$ id $=1694 \&$ Itemid $=426$

Laksono, P. M., A. Rianti, A. Hendrijani, B. Gunawan, A. Mandacan, and M. Mansoara. 2001. Igya Ser Hanjop Masyarakat Arfak dan Konsep Konservasi. [Igya Ser Hanjop: a conservation concept of Arfak Community]. KEHATI, PSAP-UGM, YBLBC. Yogyakarta, Indonesia.

Mansoeben, J. R. 1995. Sistem politiktradisional di Irian Jaya, Indonesia. [The traditional political system in Irian Jaya, Indonesia]. Lembaga Ilmu Pengetahuan Indonesia dan RIJKS Universiteit te Leiden, Jakarta, Indonesia.

Marti, S. 2008. Losing ground: the human rights impacts of oil palm plantation expansion in Indonesia. Friends of the Earth, Life Mosaic and Sawit Watch, London, UK.

McCarthy, J. F., 2010. Processes of inclusion and adverse incorporation: oil palm and agrarian change in Sumatra, Indonesia. Journal of Peasant Studies 37(4):821-850. http://d x.doi.org/10.1080/03066150.2010.512460

McCarthy, J. F., and R. A. Cramb. 2009. Policy narratives, landholder engagement, and oil palm expansion on the Malaysian and Indonesian frontiers. Geographical Journal 175(2):112-113. http://dx.doi.org/10.1111/j.1475-4959.2009.00322. $\underline{\mathrm{x}}$

Ministry of Agriculture. 2011. Statistik Perkebunan 2008-2010. [Tree Crop Estate Statistics 2008-2010]. Directorate General of Estate Crops, Ministry of Agriculture, Jakarta, Indonesia.

Ministry of Energy and Mineral Resources. 2006. Blueprint Pengembangan Bahan Bakar Nabati untuk Percepatan Pengurangan Kemiskinan dan Pengangguran 2006-2025. [Blueprint for biofuel development to reduce poverty and unemployment 2006-2025]. Ministry of Energy and Mineral Resources, Jakarta, Indonesia. 
Ministry of Environment. 2009. Report on the convention on biological diversity (the fourth national report). Ministry of Environment, Jakarta, Indonesia.

Orth, M. 2007. Subsistence foods to export goods: the impact of an oil palm plantation on local food sovereignty North Barito, Central Kalimantan, Indonesia. Sawit Watch, Bogor, Indonesia.

Oxfam. 2008. Another inconvenient truth: how biofuel policies are deepening poverty and accelerating climate change. Oxfam Briefing Paper. Oxfam, Oxford, UK.

PEACE. 2007. Indonesia and climate charge: current status and policies. PEACE, Jakarta, Indonesia. [online] URL: http: //siteresources.worldbank.org/INTINDONESIA/Resources/ Environment/ClimateChange_Full_EN.pdf

Pertamina. 2011. Kepastian Pembelian Biofuel Oleh Pertamina. [Assurances of the purchase of biofuels by Pertamina]. Pertamina, Jakarta, Indonesia. [online] URL: htt p://www.kadin-indonesia.or.id/doc/energy/9\%20-\%20Presentasi\% 20Biofuel\%20(Pertamina).pdf

Potter, L., and J. Lee. 1998. Tree planting in Indonesia: trends, impacts and directions. Occasional Paper No. 18. Center for International Forestry Research, Bogor, Indonesia.

Reinhardt, G., N. Rettenmaier, S. Gärtner, and A. Pastowski. 2007. Rain forest for biodiesel? Ecological effects of using palm oil as a source of energy. WWF, Frankfurt, Germany.

Sandker, M., A. Suwarno, and B. M. Campbell. 2007. Will forests remain in the face of oil palm expansion? Simulating change in Malinau, Indonesia. Ecology and Society 12(2): 37. [online] URL: http://www.ecologyandsociety.org/vol12/iss $2 /$ art371

Schwarz, A. 2010. Low carbon growth in Indonesia. Bulletin of Indonesian Economic Studies 46(2):181-185. http://dx.doi. org/10.1080/00074918.2010.503562

Sheil, D., A. Casson, E. Meijaard, M. van Nordwijk, J. Gaskell, J. Sunderland-Groves, K. Wertz, and M. Kanninen. 2009. The impacts and opportunities of oil palm in Southeast Asia: what do we know and what do we need to know? Occasional Paper No. 51. Center for International Forestry Research, Bogor, Indonesia.

Sirait, M. 2009. Indigenous peoples and oil palm plantation expansion in West Kalimantan, Indonesia. Universiteit van Amsterdam, The Hague, the Netherlands.

Slette, J. P., and I. E. Wiyono. 2011. Oilseeds and products update 2011. USDA Foreign Agricultural Service, Washington, D.C., USA. [online] URL: http://www.usdaindo nesia.org/public/uploaded/Oilseeds\%20and\%20Products\% 20Update Jakarta_Indonesia_1-28-2011.pdf
Suebu, B. 2009. A global solution: building a low-carbon economy for Papua province, Indonesia. Papua Provincial Government, Jayapura, Indonesia.

Telapak. 2000. Planting disaster: biodiversity, social economy, and human rights issues in large-scale oil palm plantation in Indonesia. Telapak Indonesia, Bogor, Indonesia.

Teoh, C. H. 2010. Key sustainability issues in the palm oil sector: a discussion paper for multi-stakeholders consultations. World Bank Group, Washington D.C., USA.

Tim Nasional Pengembangan Bahan Bakat Nabati (Timnas BBN). 2007. Bahan Bakar Nabati: Bahan Bakar Alternatif dari Tumbuhan sebagai Pengganti Minyak Bumi dan Gas. [Biofuels: renewable fuels as an alternative to oil and gas]. Penebar Swadaya, Jakarta, Indonesia.

United States Geological Survey (USGS). 2011. Landsat archive. USGS, Sioux Falls, South Dakota, USA. [online] URL: http://glovis.usgs.gov/

USAID. 2009. Kebijakan umum provinsi Papua untuk mempromosikan penanaman modal di bidang bahan bakar nabati $(B B N)$. [The policy and regulatory framework in Papua to promote investment in biofuels]. USDA Environmental Service Program, Jakarta, Indonesia.

Wakker, E. 2005. Greasy palms: the social and ecological impacts of large-scale oil palm plantation development in Southeast Asia. Friends of the Earth, London, UK.

World Bank. 2010. Environmental, economic, and social impacts of oil palm in Indonesia: a synthesis of opportunities and challenges. Discussion Paper. World Bank, Washington D.C., USA.

Yaap, B., M. J. Struebig, G. Paoli, and L. P. Koh. 2010. Mitigating the biodiversity impacts of oil palm development. $C A B$ Reviews: Perspectives in Agriculture, Veterinary Science, Nutrition and Natural Resources 5(019):1-11. http:// dx.doi.org/10.1079/PAVSNNR20105019

Zakaria, A., C. Theile, and L. Khaimur. 2007. Policy, practice, pride and prejudice: review of legal, environmental and social practices of oil palm plantation companies of the Wilmar Group in Sambas District, West Kalimantan (Indonesia). Friends of the Earth Netherlands, Lembaga Gemawan, and KONTAK Rakyat Borneo, Amsterdam, the Netherlands.

Zimmer-Tamakoshi, L. 1997. The last big man: development and men's discontents in the Papua New Guinea highlands. Oceania 68(2):107-122. [online] URL: http://www.jstor.org/ stable/40331612 